

\section{Potential for Development of Solar and Wind Resource in Bhutan}

\author{
Paul Gilman
}

Contractor

Shannon Cowlin and Donna Heimiller

National Renewable Energy Laboratory

Prepared under Task No. WF3N.8001
Technical Report NREL/TP-6A2-46547

September 2009






\section{NOTICE}

This report was prepared as an account of work sponsored by an agency of the United States government. Neither the United States government nor any agency thereof, nor any of their employees, makes any warranty, express or implied, or assumes any legal liability or responsibility for the accuracy, completeness, or usefulness of any information, apparatus, product, or process disclosed, or represents that its use would not infringe privately owned rights. Reference herein to any specific commercial product, process, or service by trade name, trademark, manufacturer, or otherwise does not necessarily constitute or imply its endorsement, recommendation, or favoring by the United States government or any agency thereof. The views and opinions of authors expressed herein do not necessarily state or reflect those of the United States government or any agency thereof.

Available electronically at http://www.osti.gov/bridge

Available for a processing fee to U.S. Department of Energy and its contractors, in paper, from:

U.S. Department of Energy

Office of Scientific and Technical Information

P.O. Box 62

Oak Ridge, TN 37831-0062

phone: 865.576 .8401

fax: 865.576 .5728

email: mailto:reports@adonis.osti.gov

Available for sale to the public, in paper, from:

U.S. Department of Commerce

National Technical Information Service

5285 Port Royal Road

Springfield, VA 22161

phone: 800.553 .6847

fax: 703.605.6900

email: orders@ntis.fedworld.gov

online ordering: http://www.ntis.gov/ordering.htm 


\section{Acknowledgments}

This work was funded by the U.S. Agency for International Development's (USAID) South Asia Regional Initiative for Energy (SARI/Energy). The authors wish to thank S. Padmanaban and SARI/Energy for their support of this work. The authors also wish to thank Mewang Gyeltshen and colleagues at the Renewable Energy Division, Department of Energy, Ministry of Economic Affairs, Royal Government of Bhutan for their thoughtful review of the document, as well as Mike Meshek of NREL for his editorial support. Finally, the authors thank the NREL resource assessment teams led by Dave Renné (solar) and Dennis Elliott (wind) who were responsible for development of the resource data used in this report. 


\section{Executive Summary}

With support from the U.S. Agency for International Development (USAID), the U.S. Department of Energy's National Renewable Energy Laboratory (NREL) produced maps and data of the wind and solar resources in Bhutan. The solar resource data show that Bhutan has an adequate resource for flat-plate collectors, with annual average values of global horizontal solar radiation ranging from 4.0 to $5.5 \mathrm{kWh} / \mathrm{m}^{2}$-day (4.0 to 5.5 peak sun hours per day). Although some of the best potential is in northern areas with low population densities, the solar resource throughout the country is suitable for photovoltaic development. Some areas close to transmission lines may provide prospects for photovoltaic power generation projects. The resource for concentrating collectors is less promising, with annual average values of direct normal solar radiation ranging from 2.5 to $5.0 \mathrm{kWh} / \mathrm{m}^{2}$-day. The best resource for concentrating collectors is in the high-altitude areas in the north of the country, far from electric transmission infrastructure and load centers. The wind resource data show some areas with moderate to excellent potential in several valleys throughout the country, including a few locations near power transmission lines with good-to-excellent resource potential. Areas of good wind potential indicate where wind measurement equipment could be installed to further study the resource. Because of Bhutan's complex terrain and land cover variation, more data based on ground measurements are required to improve understanding of the wind characteristics, particularly in valleys. The information provided in this report may be of use to energy planners in Bhutan involved in developing energy policy or planning wind and solar projects, and to energy analysts around the world interested in gaining an understanding of Bhutan's wind and solar energy potential. 


\section{Table of Contents}

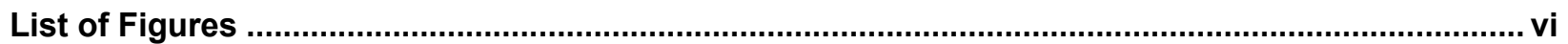

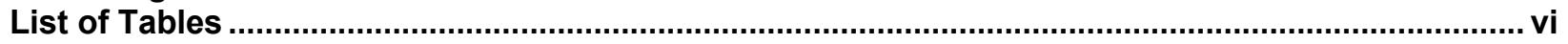

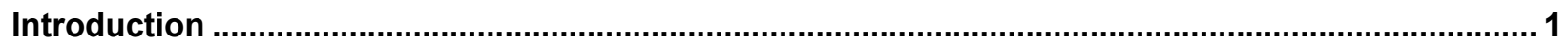

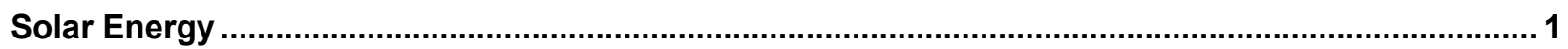

Solar Resource Mapping Methodology ...............................................................

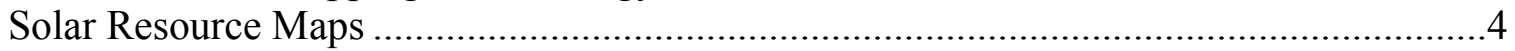

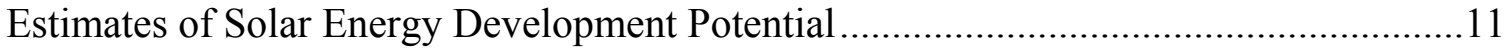

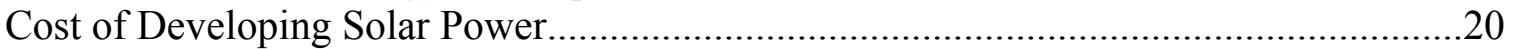

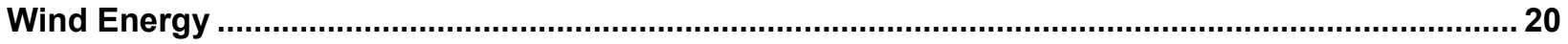

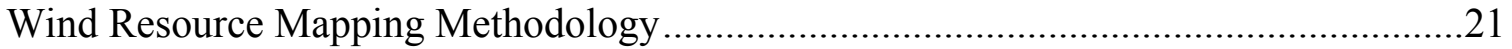

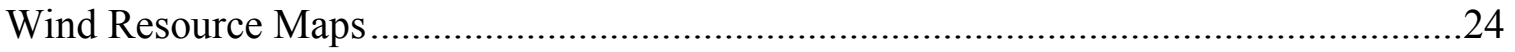

Estimates of Wind Energy Development Potential ..................................................25

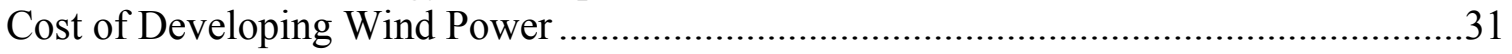

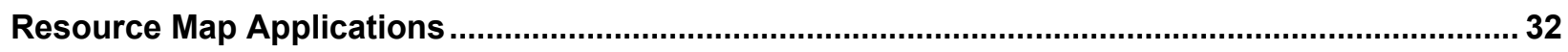

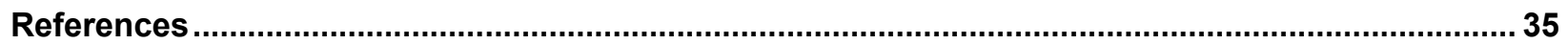




\section{List of Figures}

Figure 1. Annual average direct normal solar radiation (DNI) .............................................

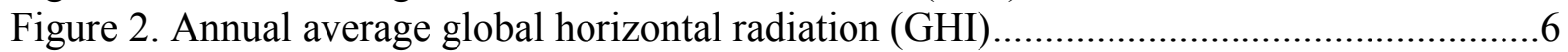

Figure 3. Seasonal average global horizontal radiation (GHI) ............................................

Figure 4. Annual average global solar radiation at latitude tilt................................................ 8

Figure 5. Seasonal average global solar radiation at latitude tilt ............................................. 8

Figure 6. Annual average global solar radiation at latitude tilt showing location of transmission lines.

Figure 7. Elevation data used in the final phase of the wind resource analysis showing terrain

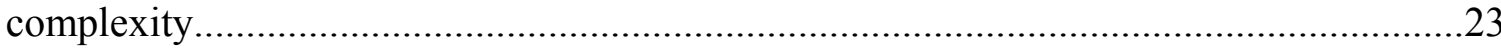

Figure 8. Tree cover data used in the final phase of the wind resource analysis showing land

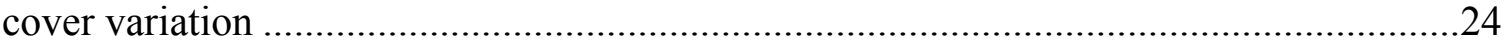

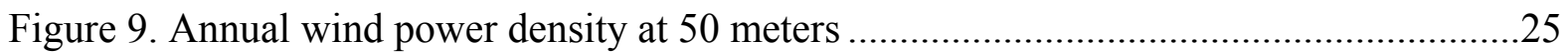

Figure 10. Wind power Class 3 and above within $5 \mathrm{~km}$ of transmission lines .......................29

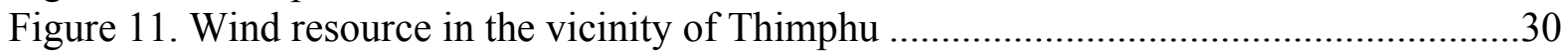

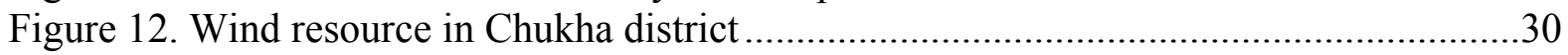

Figure 13. Wind resource in the Lhuntse Valley .....................................................................

Figure 14. Small areas of good wind potential near the Indian border....................................31

\section{List of Tables}

Table 1. Seasonal radiation in $\mathrm{kWh} / \mathrm{m} 2$-day at latitude tilt by district ...................................

Table 2. Monthly average global solar radiation at latitude tilt in $\mathrm{kWh} / \mathrm{m}^{2}$-day by district ....10

Table 3. Monthly average global solar radiation at latitude tilt in $\mathrm{kWh} / \mathrm{m}^{2}$ by city ...............10

Table 4. Total land area and resource range by district .......................................................12

Table 5. Productive land area for photovoltaic projects by district .........................................13

Table 6. Total photovoltaic technical potential: DC installed capacity in MW by district .....14

Table 7. Total photovoltaic electricity production potential by district....................................16

Table 8 . Estimated photovoltaic production potential for $1 \mathrm{MW}_{\mathrm{DC}}$ or greater projects by

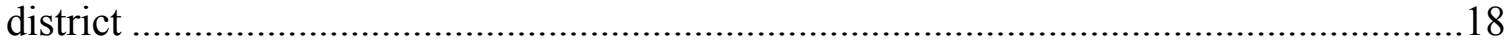

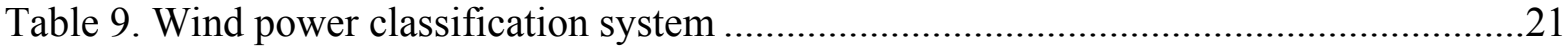

Table 10. Total technical wind potential estimate under Scenario 1 ....................................27

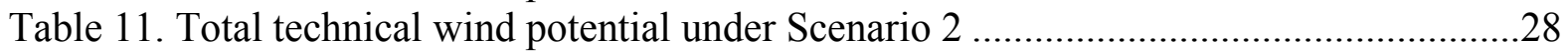

Table 12. Total technical wind potential under Scenario 3 ..................................................28 


\section{Introduction}

Bhutan is a landlocked country of about 690,000 inhabitants located between India and China. The climate varies from tropical in the southern plains to cool winters and hot summers in the central valleys, and severe winters and cool summers in the Himalayas of the north. Bhutan's population is $70 \%$ rural and $30 \%$ urban.

Bhutan's primary resource for electric power generation is hydropower. The total hydropower potential in Bhutan is estimated to be 30,000 MW, of which 1,488 MW was developed as of 2007. The Royal Government of Bhutan plans include installing a total capacity of 10,000 MW of hydropower projects by 2020, with nine proposed projects ranging in size from 400 to 4,000 MW (Gyeltshen 2008). Bhutan's annual domestic consumption of electricity in 2007 was 530 million kWh (CIA 2009).

In 2005, the Royal Government of Bhutan's Department of Energy developed the Rural Electrification Master Plan, which set a goal of $100 \%$ electrification by 2020 . Under the plan, $88 \%$ or 32,000 households would be served through extension of the national grid, and the remaining $12 \%$ or 4,400 households would be served by solar home systems and microhydropower systems. The Royal Government of Bhutan recently changed the target date from 2020 to 2013 (Gyeltshen 2009).

Electricity demand in Bhutan can be expected to grow as a result of the electrification program. Per-capita electricity consumption increased from $610 \mathrm{kWh}$ in 1998 to $949 \mathrm{kWh}$ in 2003 (Uddin 2007). More significant demand growth can also be expected, as access to low-cost electricity from the large hydropower projects attracts energy-intensive industries such as cement manufacturing and steel processing. Concerns about the potential impact of global climate change on the hydropower resource may limit future hydropower development and affect local electricity prices. Grid-connected wind and solar power projects may provide a supplemental source of electricity for local consumption in ways that are consistent with the environmental principles of Bhutan's development philosophy, as defined by the Gross National Happiness policy.

In 2008, the South Asia Regional Initiative for Energy (SARI/Energy) of the U.S. Agency for International Development (USAID) provided support to the U.S. Department of Energy's National Renewable Energy Laboratory (NREL) to produce maps and data of the wind and solar resources available in Bhutan. Estimates of Bhutan's potential wind and solar resource were developed by NREL resource assessment teams. With these new data, Bhutan can explore the potential contribution of wind and solar technologies to the country's energy mix.

\section{Solar Energy}

Solar energy systems convert part of the electromagnetic radiation that reaches Earth into usable energy. Photovoltaic (PV) systems convert the visible light portion of the radiation into electricity. Solar thermal systems convert the thermal radiation, or heat portion of the radiation reaching the collector, into usable thermal energy or electricity. Solar energy systems use collectors to absorb energy from the sun that reaches the collector in two ways:

- As direct normal radiation in a direct line from the sun

- As diffuse radiation after reflecting from the ground or particles in the atmosphere, including clouds, dust, and other particles. 
The solar resource available at a given solar energy system determines the amount of heat or electricity that it produces. The solar resource varies with location and time; with regular daily and seasonal patterns; and from year to year. Regular daily variation is caused by the apparent motion of the sun from east to west across the sky. Regular seasonal variation is caused by the apparent north-south motion of the sun and by predictable seasonal weather patterns that cause cloud cover throughout the year. The solar resource varies in less predictable ways throughout the day as clouds move across the sky, and over longer periods because of volcanic eruptions and other sources of air pollution. The growth of trees, construction of nearby tall structures, and other site-specific changes can also cause changes in the solar resource at a particular location.

Solar energy systems use either concentrating or flat-plate solar collectors to absorb the solar radiation. Concentrating collectors absorb only direct solar radiation (direct normal irradiance/DNI) and require tracking equipment to keep the collectors pointed directly at the sun. Flat-plate collectors absorb global solar radiation, which is the sum of direct radiation and diffuse radiation reaching a collector, and may or may not use tracking equipment.

Solar resource estimates depend on measurements taken on site, analysis of satellite data, or both. Solar resource maps and data based on satellite-derived data are useful for estimating energy potential for developing national energy plans, making design decisions for small-scale projects, and comparing the resource at different geographic locations. More detailed ground measurements are required for large-scale projects with high investment costs. For example, to secure financing, a $50 \mathrm{MW}$-peak, grid-connected, photovoltaic power system would typically require a solar resource assessment based on data from ground measurements at potential project sites. On the other hand, a 50 Watt-peak solar home system could be designed based on data from satellite-derived data in combination with site-specific information about shading from trees or nearby structures.

The solar resource data is often stated in kilowatt-hours per square meter per day $\left(\mathrm{kWh} / \mathrm{m}^{2}\right.$-day), which is an indication of the quantity of solar energy that strikes a collector surface over one day.

The solar resource maps and data described in this paper were developed using satellite data. The data for flat-plate collectors represent radiation data reaching a collector lying flat on the ground (global horizontal solar radiation/global horizontal irradiance/GHI) or a flat-plate collector facing the equator at an angle equal to the latitude of the location (latitude tilt). Geometry equations can be used to convert GHI data to radiation at any angle of incidence. Flat-plate collectors that employ tracking equipment to keep them directed at the sun generate maximum output. In practice, however, trade-offs between tracking equipment costs and the benefits of increased energy absorption mean that collectors fixed at latitude tilt often offer a reasonable compromise between cost and efficiency. For some systems, manually adjusting the collector orientation can improve energy absorption without a large cost increase.

Some examples of solar energy applications include:

- Photovoltaic systems convert visible light into electricity. Most photovoltaic collectors are flat-plate collectors that convert global radiation into electricity. Some photovoltaic systems employ concentrating collectors that convert DNI into electricity. Photovoltaic systems can be small enough to supply electricity to an individual household or large enough for power generation projects that supply electricity directly to the grid. 
- Concentrating solar power (CSP) systems use concentrating collectors to convert DNI into useable heat, which in turn drives steam turbines and electric generators. CSP systems are typically used in large power generation projects. CSP systems can also be used to generate process heat for industrial applications.

- Solar water heating systems typically use flat-plate collectors to heat water for either direct use or heating of household or commercial spaces.

- Solar cookers focus heat from the sun for domestic or small commercial food preparation.

- Solar air heaters preheat air for building heating systems in large commercial or industrial facilities.

\section{Solar Resource Mapping Methodology}

Researchers from NREL and the Atmospheric Sciences Research Center (ASRC) at the State University of New York (SUNY) at Albany developed the estimates of Bhutan's solar resource. SUNY researchers generated the estimates of GHI and DNI using images collected at hourly intervals between December 2002 and January 2007 from the European Meteosat 5 and 7 geostationary satellites. NREL used the GHI data to generate estimates of the resource potential at latitude tilt, and to create the solar resource maps.

The SUNY researchers analyzed pixel brightness and other properties of digital images collected from the geostationary satellite to produce solar resource estimates on a grid of $10-\mathrm{km}^{2}$ cells. In addition to the satellite image data, the researchers used these data:

- Monthly broadband aerosol optical depth (AOD)

- Monthly precipitable water

- Monthly ozone

- Terrain elevation

- Daily snow cover.

The pixel brightness was used to estimate the degree of cloud cover, expressed as cloud index, at a certain location and time. These values were adjusted for the presence of snow, which impacts the pixel brightness perceived by the satellite sensor. The cloud index was used to establish the amount of solar radiation reaching the top of the atmosphere that is transmitted toward Earth's surface rather than reflected back into space. The terrain elevation data are used to estimate the amount of atmosphere that must be traversed before incoming solar radiation reaches the surface. The AOD, precipitable water, and ozone data are used to estimate the degree of attenuation and scattering that takes place as the incoming radiation travels through the atmosphere (Perez 2002).

A recent study compared model performance with measured data at 31 stations in the United States (Myers 2005). This study examined the solar radiation output of three models, including the SUNY model based on the Geostationary Operational Environmental Satellite (GOES) satellite. Rather than compare the individual hours of measured and modeled data, this study examined the model's ability to produce data with mean and variance levels comparable to those generated from ground measurements. The SUNY model performed the best of the three studied, with an estimated uncertainty of $\pm 5 \%$ for GHI and $\pm 15 \%$ for DNI. The SUNY model was originally developed using GOES satellite imagery as a primary data input and has only recently 
been applied using the Meteosat satellites, which cover the geographic region including Bhutan. No known study comparable to the Myers investigation has compared the model performance using Meteosat data to ground measurements.

\section{Solar Resource Maps}

The following figures show some of NREL's solar resource maps for Bhutan. The complete set of full-sized maps, data, and documentation of the mapping methodology, including a general description of the solar resource, are available on the NREL Web site (NREL 2009a).

The NREL solar resource map collection includes maps of:

- DNI for concentrating solar collectors

- GHI for flat-plate collectors

- Global solar radiation at latitude tilt for flat-plate collectors.

For each of the above categories, the collection includes:

- An annual average map

- Four seasonal average maps

- Twelve monthly average maps.

The annual average maps can be used to identify and compare potential locations for project development. The seasonal and monthly maps are useful for understanding the resource at a particular location and identifying seasonal patterns in the solar resource that might complement patterns in other resources or loads.

\section{Direct Normal Solar Radiation}

Figure 1 shows the annual average DNI resource for concentrating collectors, which ranges between 2.5 and $5.0 \mathrm{kWh} / \mathrm{m}^{2}$-day. The best DNI resource is in some of the high-altitude areas in the far north of the country. 


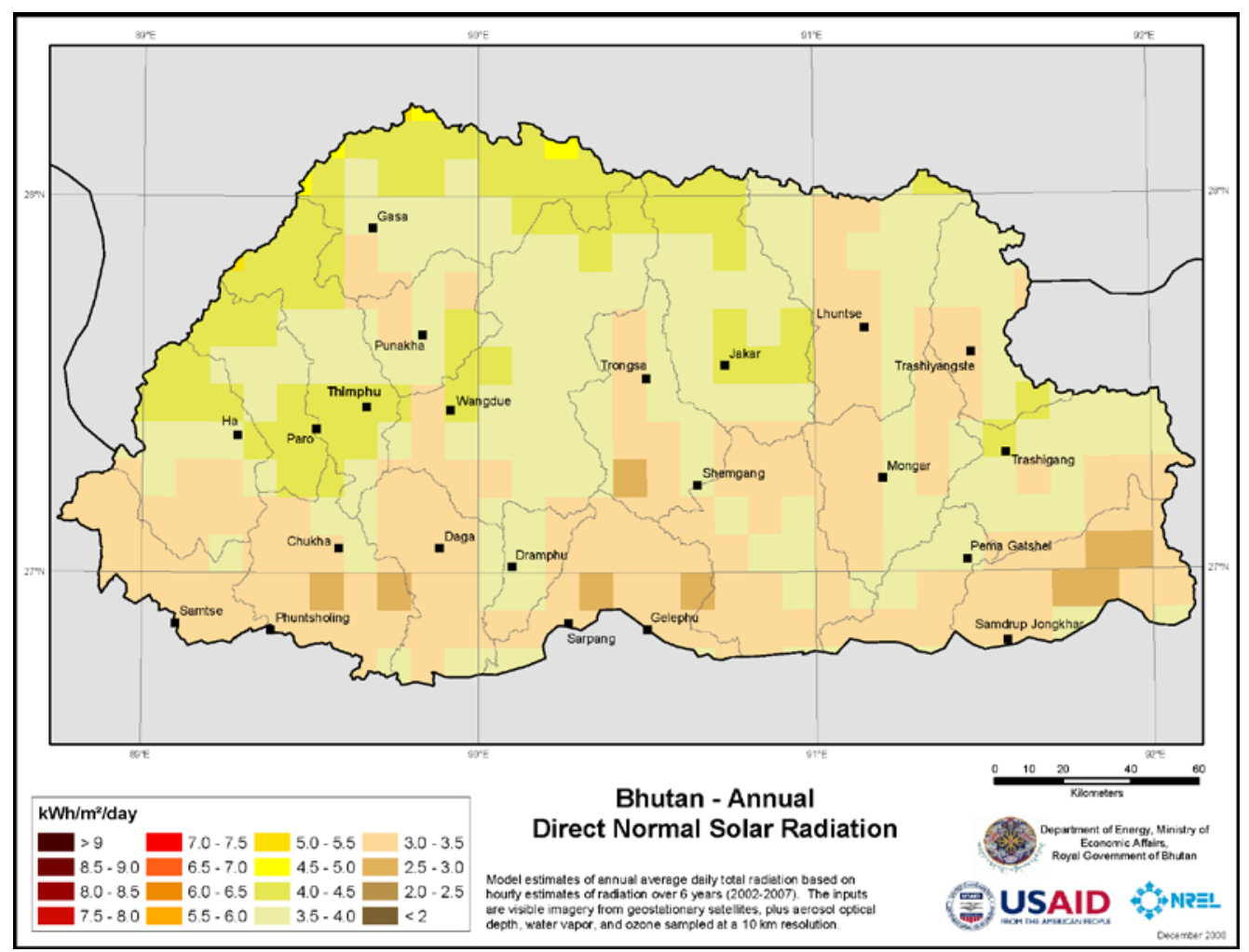

Figure 1. Annual average direct normal solar radiation (DNI)

Analysts generally consider an annual average DNI estimate of less than 6.0 or $7.0 \mathrm{kWh} / \mathrm{m}^{2}$-day to be insufficient for development of utility-scale, grid-connected, concentrating solar power systems. At such low resource levels, projects are not likely to be economically feasible. For example, an analysis of optimal sites for concentrating solar power development in the Southwestern United States excluded all locations with less than about $7.0 \mathrm{kWh} / \mathrm{m}^{2}$-day annual average DNI as potential sites for development (WGA 2006).

\section{Global Horizontal Solar Radiation}

Figure 2 shows the annual average GHI, which represents the annual energy available to a flatplate solar collector lying horizontally on the ground. The values range from 4.0 to $5.5 \mathrm{kWh} / \mathrm{m}^{2}$ day. Adequate solar resource for flat-plate collectors can be found in most of Bhutan. The best resource is in the northern part of the country, with a few areas of similar quality resource in the central-west portion near Paro and just north of Wangdue.

In Bhutan's rural electrification program, estimations of solar home system production use an annual average GHI value of $4.4 \mathrm{kWh} / \mathrm{m}^{2}$-day (Gyeltshen 2006). With the NREL solar maps, the program may revisit this estimation technique, which may lead to more robust solar home system designs. ${ }^{1}$

\footnotetext{
${ }^{1}$ System designers can use the GeoSpatial Toolkit with HOMER integration, which is available on the NREL Web site, to evaluate options for photovoltaic system designs.
} 


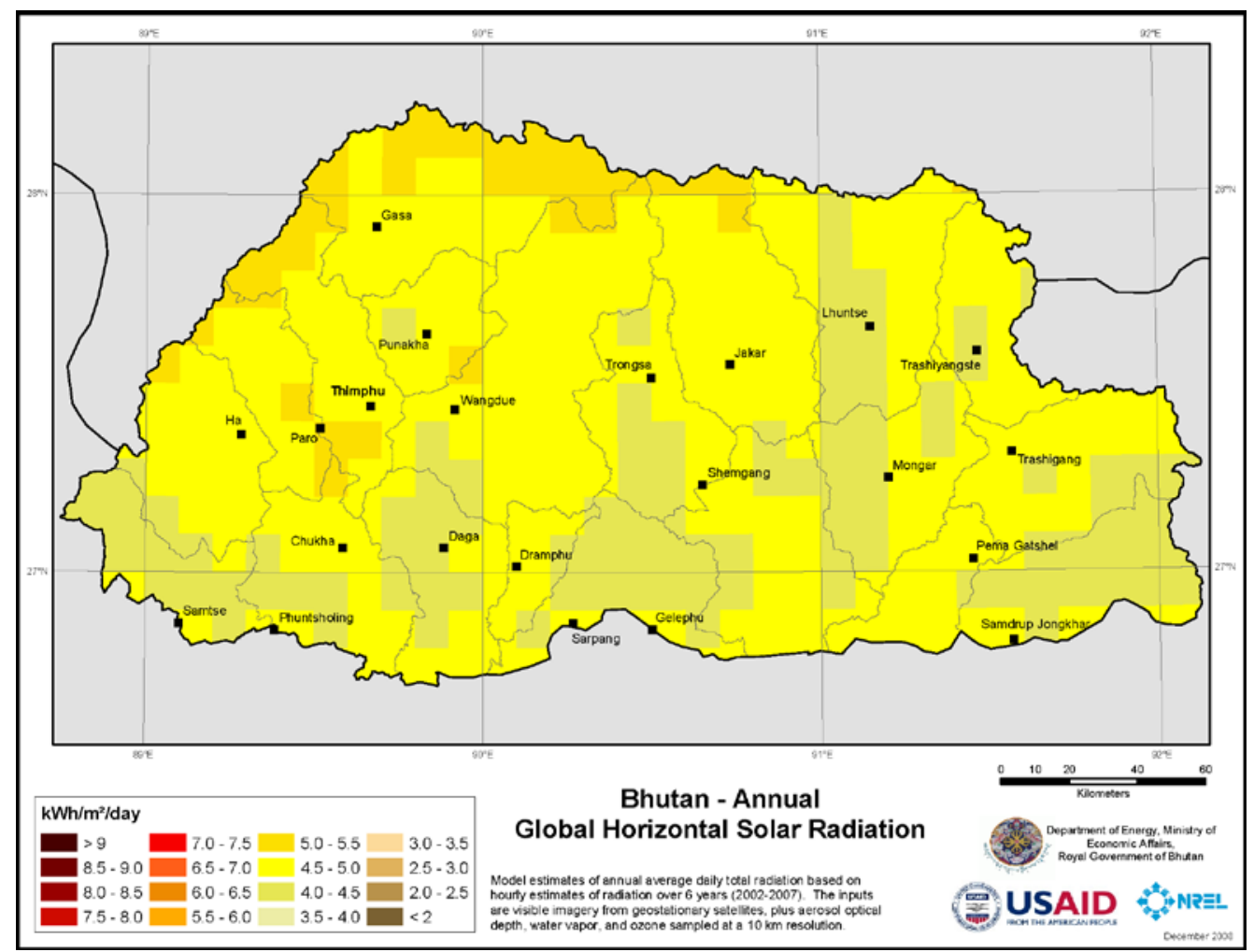

Figure 2. Annual average global horizontal radiation (GHI)

Figure 3, which shows the seasonal variation of the solar resource for flat-plate collectors, indicates a peak solar season between May and July, and a period of low resource between November and January. Detailed seasonal and monthly data for GHI are available on the NREL Web site (NREL 2009a). Tables that summarize seasonal and monthly data for each district are provided below for global solar radiation at latitude tilt, which is more useful for estimating photovoltaic system output. 

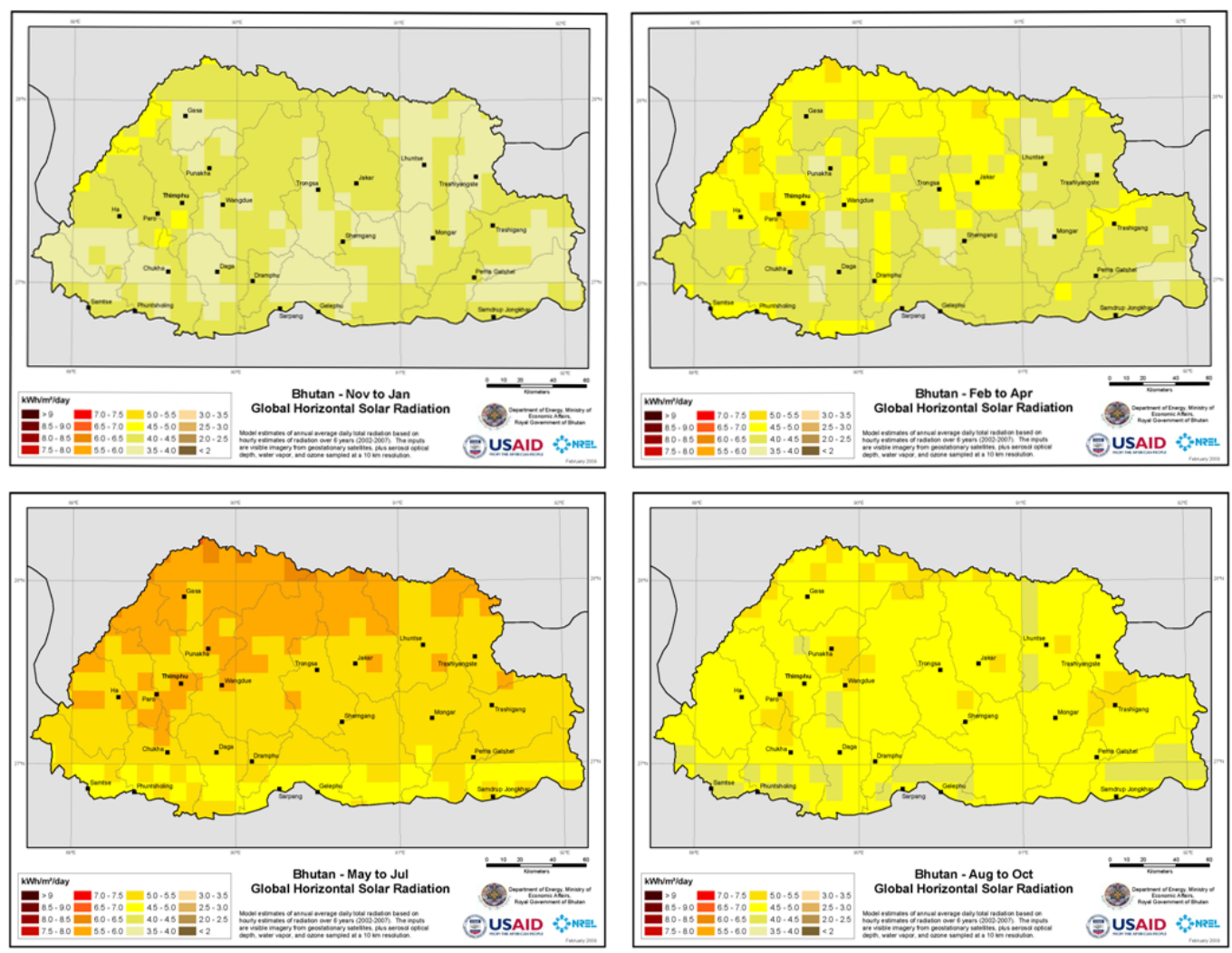

Figure 3. Seasonal average global horizontal radiation (GHI)

\section{Global Solar Radiation at Latitude Tilt}

Figure 4 shows the annual average global solar radiation for flat-plate collectors tilted at latitude (tilted at an angle equal to the latitude at the collector location). Because photovoltaic and other flat-plate solar collectors are typically installed at latitude tilt, this map indicates the amount of energy available per collector area for systems based on photovoltaic and other flat-plate collectors.

Figure 5 shows maps of the seasonal patterns in the global solar radiation at latitude tilt. Table 1 shows the data in tabulated form by district. 


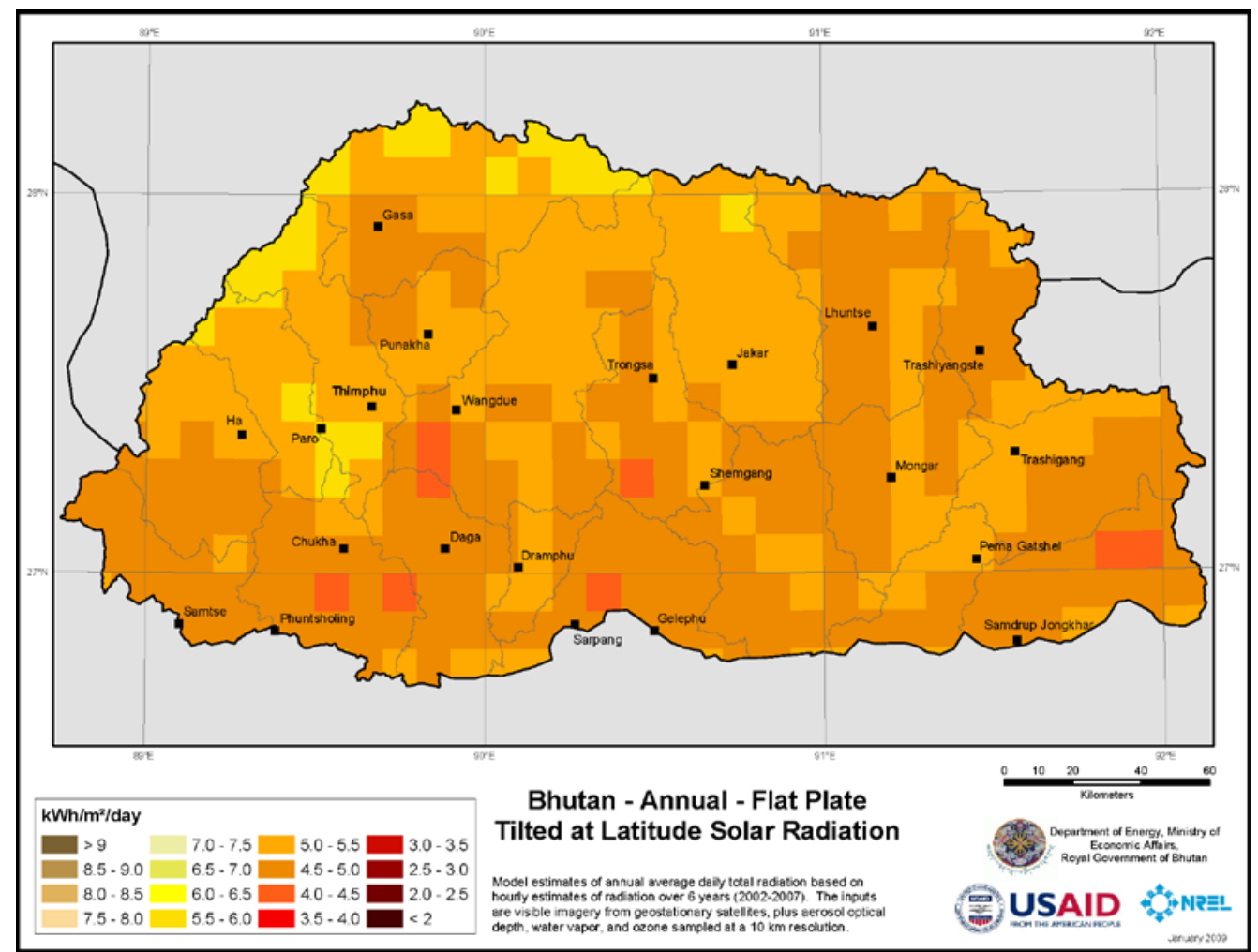

Figure 4. Annual average global solar radiation at latitude tilt

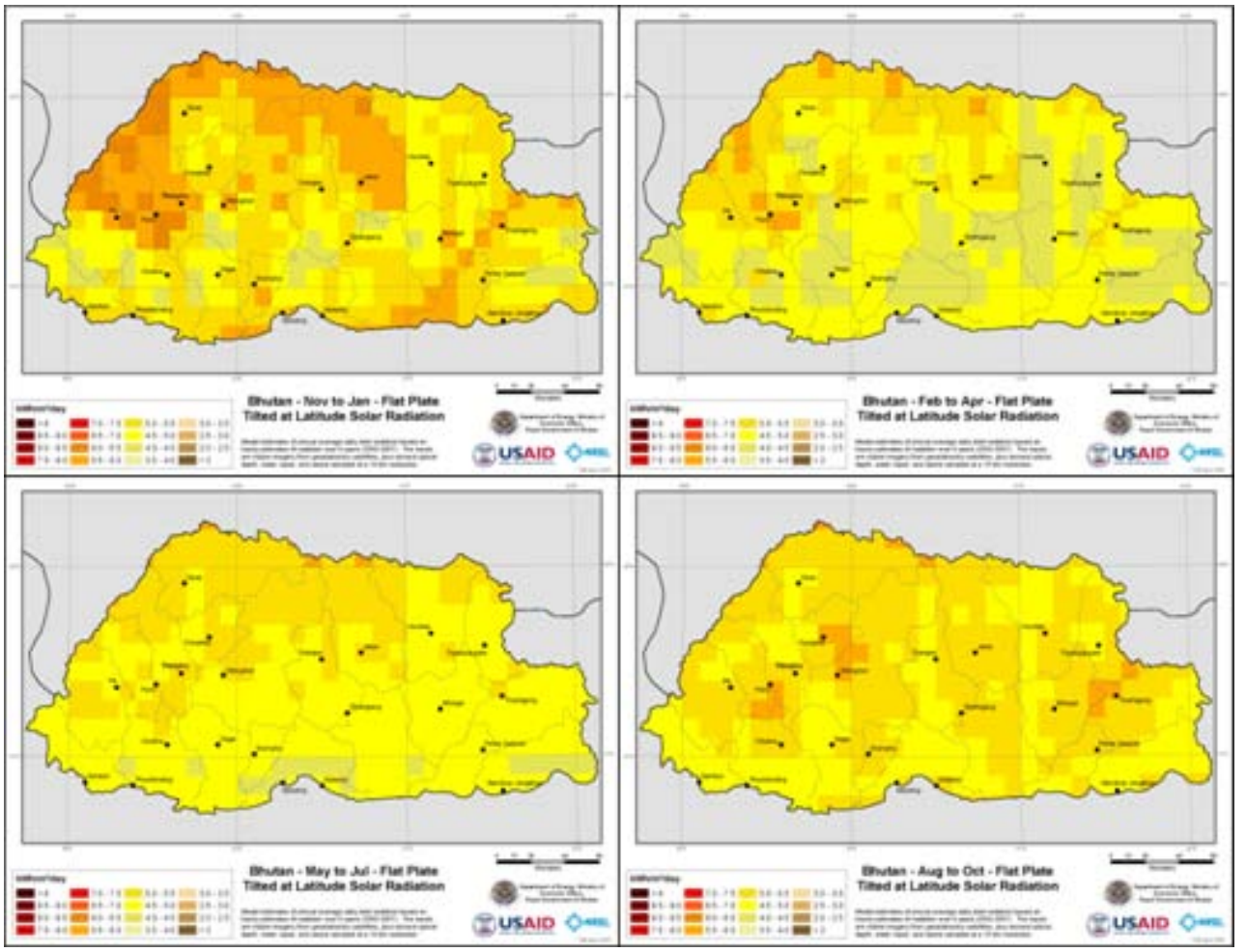

Figure 5. Seasonal average global solar radiation at latitude tilt 
Table 1. Seasonal radiation in $\mathrm{kWh} / \mathrm{m}^{2}$-day at latitude tilt by district

\begin{tabular}{lrrrr}
\hline \multicolumn{1}{c}{ District } & Nov-Jan & Feb-Apr & May-Jul & Aug-Oct \\
\cline { 2 - 5 } Bumthang & 5.64 & 5.05 & 5.10 & 5.15 \\
Chukha & 4.92 & 4.65 & 4.74 & 4.93 \\
Dagana & 5.03 & 4.53 & 4.71 & 4.92 \\
Gasa & 5.60 & 5.14 & 5.27 & 5.24 \\
Haa & 5.23 & 4.86 & 4.94 & 5.08 \\
Lhuentse & 5.02 & 4.59 & 4.99 & 4.98 \\
Monggar & 5.03 & 4.45 & 4.79 & 5.12 \\
\hline Paro & 5.89 & 5.30 & 4.99 & 5.16 \\
Pemagatshel & 5.44 & 4.76 & 4.70 & 5.12 \\
Punakha & 5.15 & 4.76 & 5.05 & 5.23 \\
Samdrupjongkhar & 4.89 & 4.42 & 4.61 & 4.83 \\
Samtse & 4.78 & 4.62 & 4.68 & 4.81 \\
Sarpang & 4.98 & 4.45 & 4.53 & 4.84 \\
\hline Thimphu & 5.87 & 5.24 & 5.10 & 5.15 \\
\hline Trashigang & 5.12 & 4.63 & 4.85 & 5.17 \\
\hline Trongsa & 4.99 & 4.55 & 4.91 & 5.07 \\
Tsirang & 5.22 & 4.72 & 4.75 & 5.09 \\
\hline Wangduephodrang & 5.28 & 4.83 & 5.04 & 5.17 \\
Yangtse & 5.08 & 4.63 & 4.95 & 5.11 \\
\hline Zhemgang & 5.13 & 4.53 & 4.71 & 5.07 \\
\hline
\end{tabular}

Table 2 and Table 3 show the monthly averages of global radiation at latitude tilt by district and by major city. 
Table 2. Monthly average global solar radiation at latitude tilt in $\mathrm{kWh} / \mathrm{m}^{2}$-day by district

\begin{tabular}{|c|c|c|c|c|c|c|c|c|c|c|c|c|c|}
\hline District & Jan & Feb & Mar & Apr & May & Jun & Jul & Aug & Sep & Oct & Nov & Dec & Annual \\
\hline Bumthang & 5.40 & 5.01 & 5.05 & 5.10 & 5.12 & 5.05 & 5.11 & 5.14 & 5.02 & 5.30 & 5.53 & 5.98 & 5.23 \\
\hline Chukha & 4.76 & 4.43 & 4.62 & 4.88 & 4.99 & 4.71 & 4.53 & 4.89 & 4.59 & 5.31 & 5.01 & 4.98 & 4.81 \\
\hline Dagana & 4.79 & 4.33 & 4.52 & 4.74 & 4.97 & 4.66 & 4.49 & 4.90 & 4.56 & 5.31 & 5.12 & 5.17 & 4.80 \\
\hline Gasa & 5.29 & 5.02 & 5.09 & 5.31 & 5.33 & 5.28 & 5.20 & 5.20 & 5.17 & 5.35 & 5.58 & 5.93 & 5.31 \\
\hline Haa & 5.05 & 4.78 & 4.86 & 4.94 & 4.98 & 4.93 & 4.93 & 5.09 & 4.81 & 5.36 & 5.31 & 5.35 & 5.03 \\
\hline Lhuentse & 4.71 & 4.38 & 4.57 & 4.83 & 5.01 & 5.06 & 4.89 & 4.95 & 4.91 & 5.09 & 4.98 & 5.36 & 4.90 \\
\hline Monggar & 4.71 & 4.29 & 4.39 & 4.66 & 4.91 & 4.84 & 4.64 & 5.02 & 4.93 & 5.42 & 5.21 & 5.17 & 4.85 \\
\hline Paro & 5.79 & 5.46 & 5.36 & 5.09 & 5.09 & 4.94 & 4.95 & 5.05 & 4.89 & 5.55 & 5.80 & 6.09 & 5.34 \\
\hline Pemagatshel & 5.18 & 4.69 & 4.85 & 4.74 & 5.03 & 4.62 & 4.44 & 4.97 & 4.88 & 5.51 & 5.61 & 5.54 & 5.00 \\
\hline Punakha & 5.08 & 4.65 & 4.72 & 4.93 & 5.08 & 5.09 & 4.97 & 5.24 & 4.98 & 5.48 & 5.01 & 5.36 & 5.05 \\
\hline $\begin{array}{l}\text { Samdrup- } \\
\text { jongkhar }\end{array}$ & 4.68 & 4.26 & 4.46 & 4.56 & 4.79 & 4.57 & 4.45 & 4.77 & 4.62 & 5.11 & 5.03 & 4.98 & 4.69 \\
\hline Samtse & 4.60 & 4.28 & 4.65 & 4.92 & 5.00 & 4.58 & 4.47 & 4.73 & 4.52 & 5.19 & 4.89 & 4.84 & 4.72 \\
\hline Sarpang & 4.74 & 4.29 & 4.47 & 4.60 & 4.83 & 4.45 & 4.31 & 4.77 & 4.51 & 5.24 & 5.13 & 5.08 & 4.70 \\
\hline Thimphu & 5.75 & 5.30 & 5.27 & 5.14 & 5.17 & 5.07 & 5.06 & 5.10 & 4.94 & 5.42 & 5.73 & 6.14 & 5.34 \\
\hline Trashigang & 4.89 & 4.55 & 4.61 & 4.74 & 4.90 & 4.95 & 4.70 & 5.09 & 5.03 & 5.38 & 5.20 & 5.26 & 4.94 \\
\hline Trongsa & 4.70 & 4.39 & 4.54 & 4.71 & 4.87 & 4.94 & 4.91 & 5.10 & 4.83 & 5.28 & 5.04 & 5.22 & 4.88 \\
\hline Tsirang & 4.91 & 4.54 & 4.72 & 4.90 & 5.07 & 4.68 & 4.50 & 5.03 & 4.71 & 5.53 & 5.43 & 5.31 & 4.94 \\
\hline $\begin{array}{l}\text { Wangdue- } \\
\text { phodrang }\end{array}$ & 5.06 & 4.71 & 4.81 & 4.96 & 5.07 & 5.06 & 4.99 & 5.17 & 4.98 & 5.37 & 5.26 & 5.52 & 5.07 \\
\hline Yangtse & 4.86 & 4.51 & 4.61 & 4.78 & 4.98 & 5.02 & 4.85 & 5.07 & 5.01 & 5.27 & 5.01 & 5.37 & 4.94 \\
\hline Zhemgang & 4.85 & 4.39 & 4.57 & 4.63 & 4.94 & 4.65 & 4.55 & 5.00 & 4.78 & 5.42 & 5.28 & 5.26 & 4.85 \\
\hline National & 4.99 & 4.62 & 4.74 & 4.88 & 5.02 & 4.90 & 4.80 & 5.03 & 4.86 & 5.33 & 5.26 & 5.43 & 4.99 \\
\hline
\end{tabular}

Table 3. Monthly average global solar radiation at latitude tilt in $\mathrm{kWh} / \mathrm{m}^{2}$ by city

\begin{tabular}{|c|c|c|c|c|c|c|c|c|c|c|c|c|c|}
\hline City & Jan & Feb & Mar & Apr & May & Jun & Jul & Aug & Sep & Oct & Nov & Dec & Annual \\
\hline Chukha & 4.71 & 4.14 & 4.34 & 4.78 & 4.81 & 4.90 & 4.87 & 5.16 & 4.69 & 5.26 & 4.82 & 4.77 & 4.77 \\
\hline Daga & 4.35 & 3.99 & 4.10 & 4.61 & 4.82 & 4.67 & 4.56 & 4.84 & 4.54 & 5.19 & 4.95 & 4.91 & 4.63 \\
\hline Damphu & 4.96 & 4.36 & 4.50 & 4.84 & 5.13 & 4.69 & 4.44 & 5.17 & 4.81 & 5.77 & 5.39 & 5.40 & 4.96 \\
\hline Gasa & 4.98 & 4.35 & 4.62 & 5.03 & 5.00 & 5.10 & 5.05 & 4.82 & 4.92 & 4.91 & 4.96 & 5.43 & 93 \\
\hline Gelephu & .20 & 4.63 & 4.80 & 4.60 & 4.99 & 4.41 & 4.32 & 4.87 & 4.61 & 5.54 & 5.56 & 5.58 & 4.9 \\
\hline $\mathrm{Ha}$ & 37 & 5.20 & .18 & .93 & .08 & 4.91 & 4.81 & 2 & 4.85 & 63 & .79 & .71 & .21 \\
\hline Jakar & .83 & 5.41 & 5.27 & 5.19 & 5.14 & 4.86 & 5.02 & 5.18 & 4.97 & 5.73 & 5.68 & .04 & .36 \\
\hline Lhuntse & 4.60 & 4.23 & 4.19 & 4.58 & 4.82 & 4.95 & 4.81 & 4.93 & 4.88 & 5.26 & 4.76 & 5.06 & 4.76 \\
\hline Mongar & 4.27 & 3.87 & 3.98 & 4.43 & 4.82 & 4.84 & 4.62 & 4.91 & 4.89 & 5.27 & 4.89 & 4.86 & 4.64 \\
\hline Paro & 5.99 & 5.72 & 5.80 & 5.38 & 5.51 & 4.99 & 4.96 & 5.36 & 5.23 & 6.12 & 6.02 & 6.06 & 0.55 \\
\hline Pema & 99 & 4.59 & 4.77 & 4.79 & 5.02 & 4.81 & 4.55 & 5.11 & 5.09 & 5.57 & 5.65 & 5.3 & .0 \\
\hline Phuntsho & 04 & 4.62 & 5.04 & 5.04 & 5.18 & 4.34 & 4.09 & 4.64 & 4.46 & 5.54 & 5.30 & 5.40 & .89 \\
\hline Punakha & 5.12 & 4.73 & 4.79 & 5.00 & 5.29 & 5.10 & 4.99 & 5.55 & 5.27 & 5.87 & 5.18 & 5.42 & $5.1 \mathrm{c}$ \\
\hline Samdrup & 5.09 & 4.63 & 4.74 & 4.66 & 4.93 & 4.52 & 4.52 & 4.87 & 4.73 & 5.37 & 5.38 & 5.47 & 4.9 \\
\hline Samtse & 5.09 & 4.77 & 5.33 & 5.26 & 5.44 & 4.54 & 4.12 & 4.81 & 4.67 & 5.79 & 5.57 & 5.59 & .08 \\
\hline Sarpang & 5.21 & 4.64 & 4.76 & 4.58 & 4.96 & 4.34 & 4.16 & 4.85 & 4.57 & 5.55 & 5.58 & 5.61 & .90 \\
\hline She & 4.88 & 4.47 & 4.60 & 4.72 & 4.95 & 4.83 & 4.83 & 5.25 & 5.04 & 5.81 & 5.43 & 5.45 & .0 \\
\hline Thimphu & 6.03 & 5.63 & 5.57 & 5.23 & 5.21 & 4.95 & 4.98 & 5.17 & 4.94 & 5.70 & 5.67 & 6.14 & 5.43 \\
\hline Trashigang & 5.17 & 5.00 & 5.09 & 5.12 & 5.26 & 4.97 & 4.78 & 5.56 & 5.47 & 6.00 & 5.85 & 5.61 & 5.32 \\
\hline Trashi-ya & 4.57 & 4.15 & 4.14 & 4.53 & 4.72 & 4.98 & 4.77 & 4.95 & 4.80 & 5.13 & 4.71 & 5.04 & 4.71 \\
\hline Tro & 4.87 & 4.47 & 4.51 & 4.60 & 4.67 & 4.86 & 4.90 & 5.01 & 4.70 & 5.09 & 5.04 & 5.40 & 4.84 \\
\hline Wangdue & 5.30 & 5.24 & 5.36 & 5.26 & 5.35 & 5.12 & 4.94 & 5.49 & 5.14 & 6.01 & 5.61 & 5.69 & 5.3 \\
\hline
\end{tabular}




\section{Estimates of Solar Energy Development Potential}

The following two scenarios describe the potential for development of photovoltaic projects in Bhutan. The scenarios do not include concentrating solar power estimates because the solar resource data do not show sufficient DNI for economical large-scale development of concentrating solar power projects. The area showing the highest DNI resource is in the far north of the country, where the steep terrain and distance from load centers and transmission lines preclude economical project development.

Resource maps of the GHI and global radiation at latitude tilt for flat-plate collectors show that Bhutan has moderate solar resources for photovoltaic project development across the country. The first solar scenario describes the total technical potential for alternating current (AC) and direct current (DC) photovoltaic projects. The second scenario describes the potential for development of large-scale photovoltaic generation projects.

Both scenarios are based on the latitude tilt solar resource data that NREL used to develop the maps, and the following assumptions:

- Five percent (5\%) of Bhutan's total land area is available for solar development.

- Of the $5 \%$ of land available for development, $30 \%$ could be covered by photovoltaic arrays.

- Photovoltaic arrays convert $10 \%$ of the available solar radiation into DC electric output. This efficiency value is for a complete array rather than a single module.

- Photovoltaic arrays are tilted toward the equator at an angle equal to the location's latitude.

Table 4 shows the total land area of each district and its range of annual average global solar resource at latitude tilt. These land areas are used in the potential estimates below. 
Table 4. Total land area and resource range by district

\begin{tabular}{lcc}
\hline \multicolumn{1}{c}{ District } & Total Land Area $\left.\mathbf{( k m}^{2}\right)$ & $\begin{array}{c}\text { Range of Annual Solar Resource } \\
\text { at Tilt = Latitude }\left(\mathbf{k W h} / \mathbf{m}^{2} \text {-day) }\right.\end{array}$ \\
\hline Bumthang & 2,718 & 4.5 to 5.6 \\
Chukha & 1,880 & 4.4 to 5.6 \\
Dagana & 1,723 & 4.4 to 5.1 \\
Gasa & 3,135 & 4.8 to 6.0 \\
Haa & 1,905 & 4.5 to 5.7 \\
Lhuntse & 2,859 & 4.5 to 5.5 \\
Mongar & 1,945 & 4.6 to 5.3 \\
Paro & 1,287 & 4.7 to 5.8 \\
Pemagatshel & 1,022 & 4.7 to 5.2 \\
Punakha & 1,110 & 4.6 to 5.4 \\
Samdrup Jongkhar & 1,877 & 4.4 to 5.1 \\
Samtse & 1,305 & 4.5 to 5.1 \\
Sarpang & 1,656 & 4.4 to 5.1 \\
Thimphu & 1,796 & 4.8 to 6.1 \\
Trashigang & 2,204 & 4.5 to 5.4 \\
Trongsa & 1,814 & 4.5 to 5.2 \\
Tsirang & 638 & 4.5 to 5.1 \\
Wangdue Phodrang & 4,036 & 4.5 to 5.6 \\
Trashiyangtse & 1,449 & 4.6 to 5.4 \\
Zhemgang & 2,417 & 4.5 to 5.1 \\
Total & 38,779 & \\
\hline
\end{tabular}

\section{Photovoltaic Scenario 1: Total Technical Potential}

Scenario 1 estimates the total installed capacity potential for grid-connected photovoltaic systems to be $58,000 \mathrm{MW}_{\mathrm{DC}}$, an amount equivalent to the annual generation of about 92 million $\mathrm{kWh}_{\mathrm{DC}}$ and 82 million $\mathrm{kWh}_{\mathrm{AC}}$ of electricity.

Table 5 shows the total land area ( $\left.\mathrm{A}_{\text {Total }}\right)$ and productive land area (A $\left.\mathrm{A}_{\text {Productive }}\right)$ for each district. The total land area includes all protected and non-protected areas. The productive land area is the area that is assumed to be available for photovoltaic arrays. Five percent $(5 \%)$ of the total land area was assumed to be available for development, and thirty percent (30\%) of that area was assumed to be physically covered by photovoltaic arrays:

$$
\mathrm{A}_{\text {Productive }}=\mathrm{A}_{\text {Total }} \times 0.05 \times 0.3
$$


Table 5. Productive land area for photovoltaic projects by district

\begin{tabular}{lcc}
\hline \multicolumn{1}{c}{ District } & Total Land Area $\mathbf{( k m}^{\mathbf{2}} \mathbf{)}$ & Productive Area $\mathbf{( k m}^{\mathbf{2}} \mathbf{~}$ \\
\hline Bumthang & 2,718 & 40.77 \\
Chukha & 1,880 & 28.20 \\
Dagana & 1,723 & 25.85 \\
Gasa & 3,135 & 47.03 \\
Haa & 1,905 & 28.58 \\
Lhuntse & 2,859 & 42.89 \\
Mongar & 1,945 & 29.17 \\
Paro & 1,287 & 19.31 \\
Pemagatshel & 1,022 & 15.33 \\
Punakha & 1,110 & 16.65 \\
Samdrup Jongkhar & 1,877 & 28.16 \\
Samtse & 1,305 & 19.58 \\
Sarpang & 1,656 & 24.84 \\
Thimphu & 1,796 & 26.94 \\
Trashigang & 2,204 & 33.07 \\
Trongsa & 1,814 & 27.21 \\
Tsirang & 638 & 9.57 \\
Wangdue Phodrang & 4,036 & 60.55 \\
Trashiyangtse & 1,449 & 21.74 \\
Zhemgang & 2,417 & 36.26 \\
Total & $\mathbf{3 8 , 7 7 9}$ & $\mathbf{5 8 2}$ \\
\hline
\end{tabular}

The productive area figures in Table 5 represent initial estimates that assume an ideal scenario. Land surveys, site visits, and stakeholder meetings would produce more accurate and practical estimates. For example, Assessing the Potential for Renewable Energy on Public Lands describes an approach used to produce solar development potential estimates for government-owned lands in the United States (Kirby 2003).

The initial estimate assumes that $100 \%$ of the productive land area shown in Table 5 is developed. Table 6 shows this estimated installation potential in DC MW of photovoltaic array capacity, where:

- Productive Area (A Productive $_{\text {): }}$ The land area available to be covered by photovoltaic arrays for each district, from Table 5.

- $\quad$ CC Capacity $\left(\mathrm{P}_{\mathrm{DC}}\right)$ : The total potential installed photovoltaic capacity in DC MW-peak assuming a $10 \%$ array efficiency at standard test conditions of $1,000 \mathrm{~W}_{\mathrm{DC}} / \mathrm{m}^{2}$ :

$$
\mathrm{P}_{\mathrm{DC}}=\mathrm{A}_{\text {Productive }} \times 1,000,000 \mathrm{~m}^{2} / \mathrm{km}^{2} \times 1,000 \mathrm{~W}_{\mathrm{DC}} / \mathrm{m}^{2} \times 0.10 \times 1 \mathrm{MW} / 1,000,000 \mathrm{~W}
$$


Table 6. Total photovoltaic technical potential: DC installed capacity in MW by district

\begin{tabular}{lcc}
\hline \multicolumn{1}{c}{ District } & Productive Area $\left.\mathbf{( k m}^{\mathbf{2}}\right)$ & DC Capacity $\left(\mathbf{M W}_{\mathbf{D C}} \mathbf{)}\right.$ \\
\hline Bumthang & 40.77 & 4,100 \\
Chukha & 28.20 & 2,800 \\
Dagana & 25.85 & 2,600 \\
Gasa & 47.03 & 4,700 \\
Haa & 28.58 & 2,900 \\
Lhuntse & 42.89 & 4,300 \\
Mongar & 29.17 & 2,900 \\
Paro & 19.31 & 1,900 \\
Pemagatshel & 15.33 & 1,500 \\
Punakha & 16.65 & 1,700 \\
Samdrup Jongkhar & 28.16 & 2,800 \\
Samtse & 19.58 & 2,000 \\
Sarpang & 24.84 & 2,500 \\
Thimphu & 26.94 & 2,700 \\
Trashigang & 33.07 & 3,300 \\
Trongsa & 27.21 & 2,700 \\
Tsirang & 9.57 & 1,000 \\
Wangdue Phodrang & 60.55 & 6,100 \\
Trashiyangtse & 21.74 & 2,200 \\
Zhemgang & 36.26 & 3,600 \\
Total & 582 & $\mathbf{5 8 , 3 0 0}$ \\
\hline
\end{tabular}

The total technical potential estimates shown in Table 6 represent the theoretical potential that would be physically possible to develop given the limited set of constraints described above. As such, the value of 58,300 $\mathrm{MW}_{\mathrm{DC}}$ should be considered the upper limit of what is theoretically possible. Further study is required to identify the screening criteria for an assessment of the actual potential given economic, political, social, and other constraints on development potential. Such criteria might include:

- Project costs compare favorably to those of a competing technology.

- Government and community support exists for the project.

- Project has minimal environmental impact.

- Project site is accessible to construction crews and equipment.

\section{Average Annual Photovoltaic Production: The total annual AC electric production} potential

The estimates of total technical capacity potential in DC MW from Table 6 provide no information about the potential production of electricity. Table 7 shows the electric generation potential for both DC and AC systems based on the estimated maximum theoretical capacity potential and estimates of global radiation at latitude tilt for each district, where:

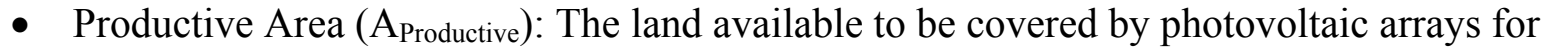
each district from Table 6

- Average Annual Solar Resource at Tilt $=$ Latitude $\left(\mathrm{R}_{\mathrm{TILT}}\right)$ is the annual average radiation at latitude tilt from Table 2 
- Average Annual DC Photovoltaic Production $\left(\mathrm{E}_{\mathrm{DC}}\right)$ is the estimated annual DC electric generation estimate for each district, assuming an array conversion efficiency of 0.10 and a derating factor of 0.86 :

$\mathrm{E}_{\mathrm{DC}}=\mathrm{A}_{\text {Productive }} \times 1,000,000 \mathrm{~m}^{2} / \mathrm{km}^{2} \times \mathrm{R}_{\mathrm{TILT}} \times 0.10 \times 0.86 \times 1$ day $/ 24 \mathrm{~h} \times 8760 \mathrm{~h} /$ year

- Average Annual $\mathrm{AC}$ Photovoltaic Production $\left(\mathrm{E}_{\mathrm{AC}}\right)$ is the estimated annual AC electric generation estimate for each district, assuming an array conversion efficiency of 0.10 and a derating factor of 0.77 :

$\mathrm{E}_{\mathrm{AC}}=\mathrm{A}_{\text {Productive }} \times 1,000,000 \mathrm{~m}^{2} / \mathrm{km}^{2} \times \mathrm{R}_{\mathrm{TILT}} \times 0.10 \times 0.77 \times 1$ day $/ 24 \mathrm{~h} \times 8760 \mathrm{~h} /$ year

The DC and AC generation estimates both assume that photovoltaic systems convert $10 \%$ of the solar radiation incident on the array to DC electricity. This $10 \%$ efficiency value represents the light-to-electricity conversion efficiency of individual modules in the array. The $86 \%$ and $77 \%$ "derating" factors used in the DC and AC generation calculations, respectively, account for system losses that occur when modules are installed in a complete system. These losses are caused by individual modules in the array having slightly different performance characteristics due to manufacturing process imperfections, electrical losses from wiring throughout the system, soiling of the array by dust, and other factors (NREL 2009c).

These generation potential estimates can be compared to Bhutan's total domestic annual consumption rate of 530 million $\mathrm{kWh} / \mathrm{yr}$, and its per capita annual consumption rate of 949 $\mathrm{kWh} / \mathrm{yr}$ discussed in the introduction. 
Table 7. Total photovoltaic electricity production potential by district

\begin{tabular}{|c|c|c|c|c|}
\hline District & $\begin{array}{c}\text { Productive Area } \\
\left(\mathrm{km}^{2}\right)\end{array}$ & $\begin{array}{c}\text { Average } \\
\text { Annual Solar } \\
\text { Resource at } \\
\text { Tilt }=\text { Latitude } \\
\text { (kWh/m }{ }^{2} \text {-day) }\end{array}$ & $\begin{array}{l}\text { Average Annual } \\
\text { DC Photovoltaic } \\
\text { Production } \\
\text { (million } \mathrm{kWh}_{\mathrm{Dc}} \mathrm{yr} \text { ) }\end{array}$ & $\begin{array}{c}\text { Average Annual } \\
\text { AC Photovoltaic } \\
\text { Production } \\
\text { (million } \mathrm{kWh}_{\mathrm{AC}} / \mathrm{yr} \text { ) }\end{array}$ \\
\hline Bumthang & 40.77 & 5.2 & 6,700 & 6,000 \\
\hline Chukha & 28.20 & 4.8 & 4,300 & 3,800 \\
\hline Dagana & 25.85 & 4.8 & 3,900 & 3,500 \\
\hline Gasa & 47.03 & 5.3 & 7,800 & 7,000 \\
\hline $\mathrm{Haa}$ & 28.58 & 5.0 & 4,500 & 4,000 \\
\hline Lhuntse & 42.89 & 4.9 & 6,600 & 5,900 \\
\hline Mongar & 29.17 & 4.8 & 4,400 & 4,000 \\
\hline Paro & 19.31 & 5.3 & 3,200 & 2,900 \\
\hline Pemagatshel & 15.33 & 5.0 & 2,400 & 2,200 \\
\hline Punakha & 16.65 & 5.0 & 2,600 & 2,400 \\
\hline Samdrup Jongkhar & 28.16 & 4.7 & 4,100 & 3,700 \\
\hline Samtse & 19.58 & 4.7 & 2,900 & 2,600 \\
\hline Sarpang & 24.84 & 4.7 & 3,700 & 3,300 \\
\hline Thimphu & 26.94 & 5.3 & 4,500 & 4,000 \\
\hline Trashigang & 33.07 & 4.9 & 5,100 & 4,600 \\
\hline Trongsa & 27.21 & 4.9 & 4,200 & 3,700 \\
\hline Tsirang & 9.57 & 4.9 & 1,500 & 1,300 \\
\hline Wangdue Phodrang & 60.55 & 5.1 & 9,600 & 8,600 \\
\hline Trashiyangtse & 21.74 & 4.9 & 3,400 & 3,000 \\
\hline Zhemgang & 36.26 & 4.8 & 5,500 & 4,900 \\
\hline Total & 582 & & 90,900 & 81,400 \\
\hline
\end{tabular}

The total DC generation estimate of nearly 91 million $\mathrm{kWh}_{\mathrm{DC}}$ per year of electricity is the theoretical potential if all productive areas are developed as DC systems. Small solar home systems for rural electrification projects are typically DC systems, so this scenario provides some insight into the maximum potential for development of such systems. For example, the DC generation estimate suggests that Bhutan's goal-providing $50 \mathrm{~W}_{\mathrm{DC}}$ solar home systems to 4,400 households by 2013, roughly equivalent to 45 thousand $\mathrm{kWh} /$ year - can easily be met from a solar resource perspective. The total AC generation estimate of 81 million $\mathrm{kWh}_{\mathrm{AC}}$ per year assumes that all productive areas are developed as AC systems. AC systems include large systems for power generation projects, smaller grid-connected systems, and stand-alone systems with inverters.

The total technical potential estimates show that Bhutan has a solar resource that can be developed for electricity generation. Further study is required to develop estimates based on realworld and non-technical constraints.

\section{Photovoltaic Scenario 2: Potential for Utility-scale Grid-connected Photovoltaic Systems}

Scenario 2 estimates the potential for developing large-scale (1 $\mathrm{MW}_{\mathrm{DC}}$ or greater) grid-tied photovoltaic plants as power generation projects. While Scenario 1 estimates are based on the assumption that five percent of all land in the country is available for development, Scenario 2 further constrains the available land to areas suitable for development of such projects. Scenario 2 excludes any land with slope greater than $5 \%$ or at a distance of more than $5 \mathrm{~km}$ from existing transmission lines. The scenario also assumes a photovoltaic density of $44 \mathrm{MW} / \mathrm{km}^{2}$, based on 
analysis of the land requirements for existing photovoltaic power generation projects. ${ }^{2}$ At this density, a $1 \mathrm{MW}_{\mathrm{DC}}$ project would require $0.023 \mathrm{~km}^{2}$ of land. Therefore, the scenario includes only contiguous land areas of $0.023 \mathrm{~km}^{2}$ or greater that meet the above requirements.

This scenario also assumes the environmental impact of large-scale projects on protected areas to be unacceptable and therefore excludes them from large-scale photovoltaic project development. However, including protected areas has a minimal impact on calculated available land area. ${ }^{3}$

Table 8 shows the land area available for developing $1 \mathrm{MW}_{\mathrm{DC}}$ or greater photovoltaic power generation projects in each district and the estimated development capacity and electric generation potential, where:

- Area Available for Development (A $\left.A_{\text {Development }}\right)$ : The land area that meets the development criteria described above (5\% or less slope, $5 \mathrm{~km}$ or nearer to existing grid, and contiguous area of $0.023 \mathrm{~km}^{2}$ or greater)

- Annual Tilt Resource Range: The minimum and maximum annual average annual solar radiation (flat-plate tilted at latitude) for the areas that meet the requirements

- Average Annual Tilt Resource $\left(\mathrm{R}_{\mathrm{TILT}}\right)$ : The annual average solar radiation (flat-plate tilted at latitude) for land that meets the criteria

- Development Capacity $\left(\mathrm{P}_{\mathrm{DC}}\right)$ : The total potential capacity for photovoltaic installations in DC MW-peak, assuming a photovoltaic density of $44 \mathrm{MWDC} / \mathrm{km}^{2}$ as described above:

$\mathrm{P}_{\mathrm{DC}, \text { Development }}=\mathrm{A}_{\text {Development }} \times 44 \mathrm{MW}_{\mathrm{DC}} / \mathrm{km}^{2}$

- Average Annual Production for Developed Projects ( $\left.E_{A C, D e v e l o p m e n t}\right)$ : The total annual AC electric production potential for $1 \mathrm{MW}_{\mathrm{DC}}$ or greater developed projects in millions of $\mathrm{kWh}_{\mathrm{AC}}$, assuming an array conversion efficiency of 0.10 , and a derating factor of 0.77 , as described for Table 7 above:

$\mathrm{E}_{\mathrm{AC}, \text { Development }}=\mathrm{A}_{\text {Development }} \times 1,000,000 \mathrm{~m}^{2} / \mathrm{km}^{2} \times \mathrm{R}_{\mathrm{TILT}} \times 0.10 \times 0.77 \times 1 \mathrm{day} / 24 \mathrm{~h} \times$ $8760 \mathrm{~h} /$ year

\footnotetext{
${ }^{2}$ For a discussion of area requirements for photovoltaic projects, see http://solarbythewatt.com/2009/03/09/ solar-energy-land-area-efficiency-or-how-much-acres-per-mw-kwp-per-acre/

${ }^{3}$ The inclusion of protected areas only slightly affects the land area estimates, increasing the developable land area in Zhemgang District from 0.47 to $0.95 \mathrm{~km}^{2}$ and in Pemagatshel District from 0.25 to $2.21 \mathrm{~km}^{2}$, resulting in a total increase of potential from 2,947 MW (9,319 million $\mathrm{kWh} / \mathrm{yr})$ to only 3,058 MW (9,672 million $\mathrm{kWh} / \mathrm{yr})$. Detailed results are included for only the analysis that excludes protected areas.
} 
Table 8. Estimated photovoltaic production potential for $1 \mathrm{MW}_{\mathrm{DC}}$ or greater projects by district

\begin{tabular}{|c|c|c|c|c|c|}
\hline Province & $\begin{array}{c}\text { Area } \\
\text { Available } \\
\text { for } \\
\text { Developme } \\
\text { nt }\left(\mathrm{km}^{2}\right)\end{array}$ & $\begin{array}{c}\text { Annual Tilt } \\
\text { Resource } \\
\text { Range } \\
\text { (kWh/m } / \mathrm{m}^{2} / \text { day) }\end{array}$ & $\begin{array}{c}\text { Average } \\
\text { Annual Tilt } \\
\text { Resource } \\
\left(\mathrm{kWh} / \mathrm{m}^{2} / \text { day }\right)\end{array}$ & $\begin{array}{c}\text { Develop } \\
\text { ment } \\
\text { Capacity } \\
\left(\mathrm{MW}_{\mathrm{DC}}\right)\end{array}$ & $\begin{array}{l}\text { Average Annual } \\
\text { Production for } \\
\text { Developed Projects } \\
\left.\text { (million kWh } \mathrm{AC}_{\mathrm{AC}} / \mathrm{yr}\right)\end{array}$ \\
\hline Chukha & 3.26 & $4.5-4.9$ & 4.85 & 143 & 444 \\
\hline Haa & 1.05 & $5.2-5.4$ & 5.29 & 46 & 156 \\
\hline Lhuntse & 0.02 & $4.7-4.7$ & 4.71 & 1 & 3 \\
\hline Mongar & 0.41 & $4.6-5.2$ & 4.83 & 18 & 56 \\
\hline Paro & 7.82 & $5.3-5.5$ & 5.38 & 344 & 1,183 \\
\hline Pemagatshel & 0.25 & $4.9-5.2$ & 5.00 & 11 & 35 \\
\hline Punakha & 0.61 & $4.8-5.1$ & 5.10 & 27 & 87 \\
\hline Samdrup Jongkhar & 0.07 & $4.8-4.9$ & 4.88 & 3 & 10 \\
\hline Samtse & 8.32 & $4.8-4.9$ & 4.88 & 366 & 1,142 \\
\hline Sarpang & 43.45 & $4.6-5.0$ & 4.88 & 1,912 & 5,955 \\
\hline Thimphu & 0.92 & $5.1-5.4$ & 5.34 & 40 & 137 \\
\hline Wangdue Phodrang & 0.32 & $4.5-5.4$ & 4.93 & 14 & 45 \\
\hline Zhemgang & 0.47 & $4.9-5.1$ & 5.00 & 20 & 65 \\
\hline Total & 66.97 & & & 2,947 & 9,319 \\
\hline
\end{tabular}

Bumthang District does not appear in the table because no land there meets the development criteria. Sarpang District, which has more flat land than other districts, has the most land area that meets the criteria. The table does not provide any information about the locations within each district that meet the criteria. Figure 6 shows the global solar radiation at latitude tilt along with the transmission lines (dotted lines) to help identify the locations. 


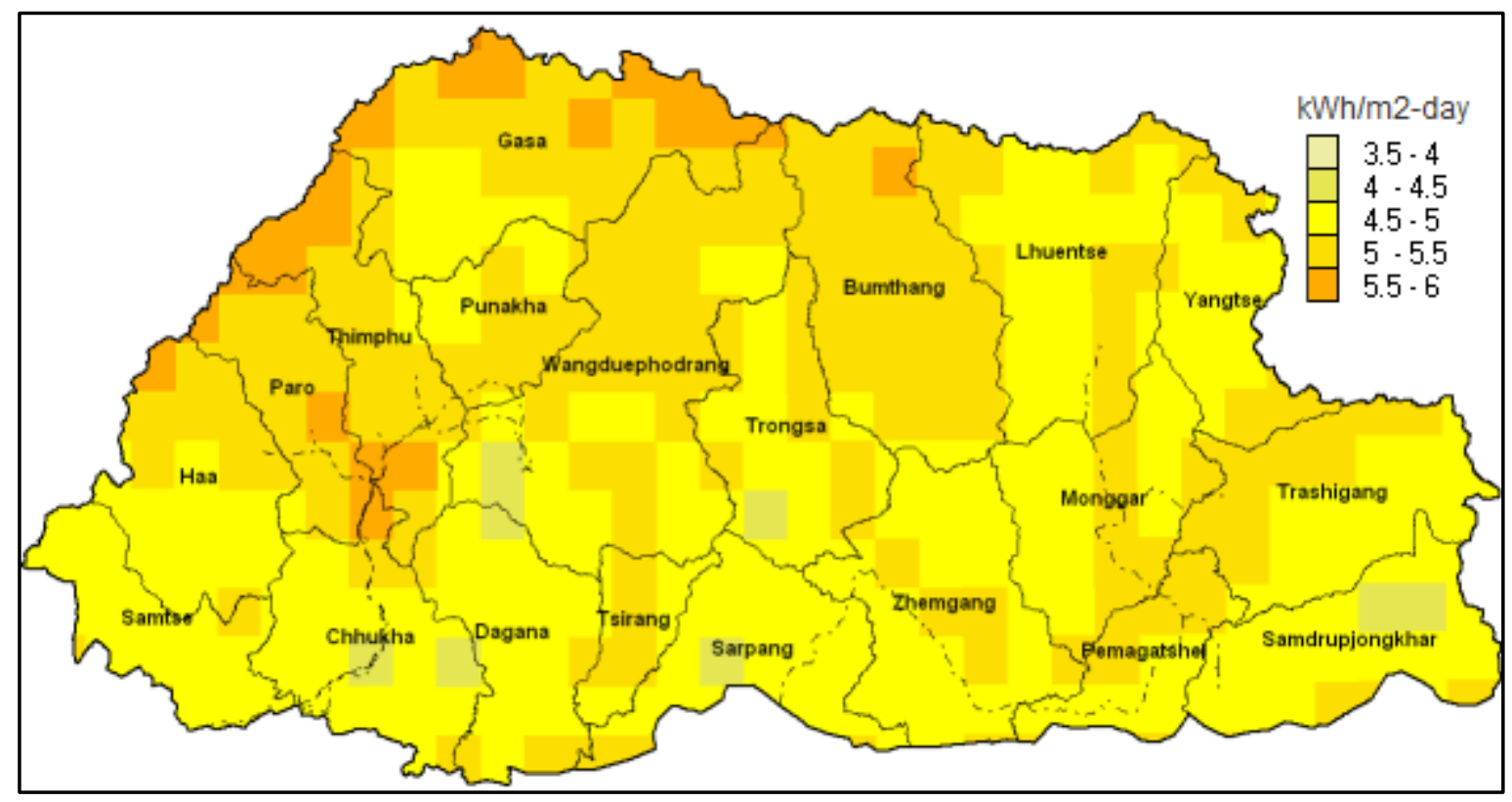

Figure 6. Annual average global solar radiation at latitude tilt showing location of transmission lines as dotted lines

Comparing the data from Table 8 with the map in Figure 6 suggests that the following areas have the largest land areas available for large-scale photovoltaic power generation project development:

- Southern Sarpang

- Southwest Samtse

- Southeast Paro

- Northern Chukha.

Although Chukha, Sarpang and Samtse districts do not appear from the resource map alone to be the most promising districts for project development, the Scenario 2 analysis shows that considering development constraints, these districts show better promise than areas with better solar resource in the mountainous north far from transmission infrastructure. Note that areas in other districts that show better solar resource with proximity to transmission lines, such as in Zhemgang and Mongar, have smaller available land areas because of the land slope and contiguous land area constraints. 


\section{Cost of Developing Solar Power}

This information is provided to help analysts make rough estimates of the cost of developing photovoltaic projects in Bhutan. Actual projects costs vary widely depending on the location, scale, and type of project.

Average photovoltaic module costs in the United States ranged between $\$ 4.45 / \mathrm{W}_{\mathrm{DC}}$ and $\$ 4.85 / \mathrm{W}_{\mathrm{DC}}$ between January 2008 and August 2009. For systems generating AC electricity, module costs typically represent between $50 \%$ and $60 \%$ of total system costs (Solarbuzz 2009a). System costs in the United States are therefore estimated to be about $\$ 9.70 / \mathrm{W}_{\mathrm{DC}}$.

The average cost of electricity from photovoltaic systems in the United States varies by market, with costs of about $40 \phi / \mathrm{kWh}$ for residential grid-connected systems, $30 \phi / \mathrm{kWh}$ for commercial systems, and $22 ф / \mathrm{kWh}$ for industrial systems (Solarbuzz 2009b).

In Bhutan, a residential system that generates DC electricity using an $80-\mathrm{W}_{\mathrm{DC}}$ photovoltaic module, an 80-Ah (at a C20 charge rate) battery, a charge controller, and three 11-W compact fluorescent light bulbs costs about $\$ 700$, an amount that is equivalent to about $\$ 8.75 / \mathrm{W}_{\mathrm{DC}}$ of photovoltaic capacity (Mewang 2009b).

\section{Wind Energy}

Wind is movement of air caused by the sun's uneven heating of Earth. Wind energy is the energy embodied in the wind as it travels over Earth's surface. The amount of energy available to a wind energy system depends on a few factors:

- Velocity or speed of the wind

- Density of the air, which is a function of the air temperature and altitude

- Cross-sectional area of capture perpendicular to Earth's surface.

The energy available in wind is proportional to the cube of the wind velocity, which means that wind energy production estimates are highly sensitive to predicted wind speeds, and potential wind energy projects require careful wind resource assessments.

Wind resource assessments indicate variations in wind speed over space and time. Friction between the moving air and the ground reduces the wind velocity, resulting in greater wind speeds at greater heights above the ground. This variation of wind speed with height above the ground is called wind shear. Topographic features, vegetation, and structures affect the flow of air across the ground and can accelerate and decelerate the wind. Wind speed and direction vary throughout the day and year, often in patterns caused by daily and seasonal weather patterns.

Wind power density, a calculation of the usable energy available in the wind, is stated in watts per square meter $\left(\mathrm{W} / \mathrm{m}^{2}\right)$ of cross-sectional area perpendicular to the ground. Table 9 shows the wind power classification system used in the NREL wind maps, which employs a numbering system to indicate the quality of the wind resource. 
Table 9. Wind power classification system

\begin{tabular}{rccc}
\hline $\begin{array}{l}\text { Wind Power } \\
\text { Class }\end{array}$ & $\begin{array}{l}\text { Resource } \\
\text { Potential }\end{array}$ & $\begin{array}{c}\text { Annual Average Wind Power } \\
\text { Density at } \mathbf{5 0} \mathbf{~ m}\left(\mathbf{W} / \mathbf{m}^{2}\right)\end{array}$ & $\begin{array}{c}\text { Annual Average Wind } \\
\text { Speed at } \mathbf{5 0 ~} \mathbf{~}(\mathbf{m} / \mathbf{s})^{4}\end{array}$ \\
\hline 1 & Poor & $0-200$ & $0.0-4.4$ \\
2 & Marginal & $200-300$ & $4.4-5.0$ \\
3 & Moderate & $300-400$ & $5.0-5.5$ \\
4 & Good & $400-500$ & $5.5-5.9$ \\
5 & Excellent & $500-600$ & $5.9-6.3$ \\
6 & & $600-800$ & $6.3-7.0$ \\
7 & & $>800$ & $>7.0$ \\
\hline
\end{tabular}

The characteristics of the wind resource at a given site depend greatly on the terrain, vegetation, and land use. Wind resource maps can be used for initial site screening and for estimates of regional wind potential. However, the maps do not provide sufficient accuracy or detail for wind energy project design. Wind energy project feasibility studies require both short-term detailed ground measurements of site variables - wind speed and direction, air temperature, and pressure observations for at least one year - and longer-term data from nearby weather stations. Suitable energy production estimates for project planning cannot be developed without these data.

Wind speed measurements should be made at turbine hub heights. To understand wind shear characteristics at the project site, speed and direction measurements should be made at more than one height above the ground whenever possible.

Wind turbine output at a given site can be predicted using wind speed data and the turbine's power curve, which describes the turbine's operating power at different wind speeds. A wind turbine generates electricity only when the wind speed is above the turbine's cut-in speed and below its cut-out speed. A wind turbine does not always generate electricity at its rated capacity. For many hours of the year, a turbine generates electricity below its rated capacity. One measure of a turbine's performance is its capacity factor, which is the ratio of the turbine's actual energy output over a given period of time to its output over the same period had it operated at its rated capacity the entire time.

Wind turbines can be used in both large-scale power generation projects and smaller selfgeneration projects. In large-scale power generation projects, wind turbines generate electricity that feeds regional grids. These projects involve the installation of several to hundreds of large wind turbines, and require: (1) sufficient land in a resource-rich environment, (2) a connection point to the power transmission system capable of absorbing the energy produced by the project, and (3) wind-friendly land-use and electric generation regulations. In smaller self-generation projects designed to meet local loads, wind turbines can be used in combination with other renewable equipment, such as solar panels, when the renewable resources are complimentary. Wind turbines can also be used in combination with conventional power equipment such as diesel generators in hybrid energy systems to reduce fuel consumption and emissions of air pollutants.

\section{Wind Resource Mapping Methodology}

NREL developed estimates of Bhutan's wind resources at a spatial resolution of $1 \mathrm{~km}^{2}$ using NREL's Wind Resource Assessment and Mapping System (WRAMS), the application of which is summarized here based on the methodology document produced by NREL's wind resource

\footnotetext{
${ }^{4}$ Wind speeds estimated assuming a Weibull $\mathrm{k}$ distribution $=1.1$ and elevation of $2000 \mathrm{~m}$.
} 
assessment team (NREL 2009b). WRAMS is a combination of analytical, numerical, and empirical methods employing geographic information system (GIS) mapping tools and data sets. Initial estimates of the wind speed and wind power density in Bhutan were generated by a mesoscale numerical model by AWS Truewind (AWST) of Albany, New York. These data were provided at levels from 30 to $200 \mathrm{~m}$ above ground on a grid of $1-\mathrm{km}^{2}$ cells. The numerical model output was adjusted based on analysis of several supplemental data sets, including surface and upper air data. The final adjusted data were used to develop the maps showing the distribution of wind power density across Bhutan.

The WRAMS analysis employed surface and upper air meteorological data sets to estimate available wind resources in Bhutan. Surface data from two sources were used. First, the integrated surface hourly (ISH) global climatic data were obtained from the U.S. National Climatic Data Center (NCDC). The ISH data set does not include any stations in Bhutan, so data near Bhutan's borders were processed to evaluate the inter-annual and monthly variability, diurnal and seasonal patterns of wind speed, and joint frequency of wind speed and direction for nearby sites. Second, surface data collected at 12 meteorological stations in Bhutan were used to analyze wind characteristics at each site, including monthly and annual average wind speed and wind power, diurnal wind patterns, and frequency of wind speed and direction. No upper-air data sets are available for Bhutan, but automated data processing (ADP) upper-air data were collected for surrounding countries and used to establish general regional wind characteristics.

In the data evaluation process, NREL used the surface and upper-air data sets to develop a conceptual model of the physical mechanisms influencing wind flow on a regional and more localized scale. The surface data sets, if screened for consistency and reasonableness based on equipment specifications and operation and maintenance history, can provide valuable contributions to this conceptual model. The upper-air data sets can provide useful information on wind flow characteristics and vertical profiles, which can be of great use for extrapolating wind speeds over elevated terrain features.

AWST developed wind speed and wind power density estimates for Bhutan using its

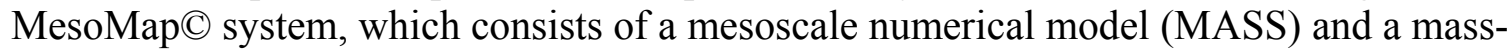
conserving wind-flow model (WindMap).

MASS was run at a horizontal resolution of $2.5 \mathrm{~km}^{2}$ to generate wind and other variables for 366 days selected randomly from 1989 to 2003 . Climatic data were used to establish the initial and boundary conditions for MASS, which then determined the evolution of these conditions throughout the simulation. MASS relies on geophysical inputs to establish surface characteristics such as surface roughness. Wind power density outputs from MASS were then scaled down to a $1 \mathrm{~km}^{2}$ grid resolution by the WindMap model. The output of these numerical models included wind speed and wind power density at a grid resolution of $1 \mathrm{~km}^{2}$ at levels between 30 and $200 \mathrm{~m}$ above Earth's surface, which were provided to NREL for use in the final analysis and validation.

The final phase of the wind resource analysis involves use of: (1) digital elevation model (DEM) terrain data, (2) wind power density values for each grid cell from the numerical modeling output, and (3) empirical adjustments to the wind power density values for each grid cell based on the conceptual model developed through evaluation of meteorological data sets.

Figure 7 and Figure 8 show the great variation in elevation and land cover in Bhutan at the 1-km grid resolution, particularly in regions with complex terrain. Consequently, the numerical modeling output resulting from averaging across these grid cell sizes may not adequately capture 
wind variations produced by surface roughness and elevation deviations. NREL compared the numerical model output to the conceptual model and identified regions where the numerical model was likely to capture inaccurately the wind resource available. This comparison suggested that the numerical model was not adequately resolving the mountain-valley circulations that result in strong winds in many of Bhutan's valley areas. Based on characterizations made during the conceptual model's development, the wind power density values were adjusted empirically to more accurately capture areas with high potential for wind development in Bhutan.

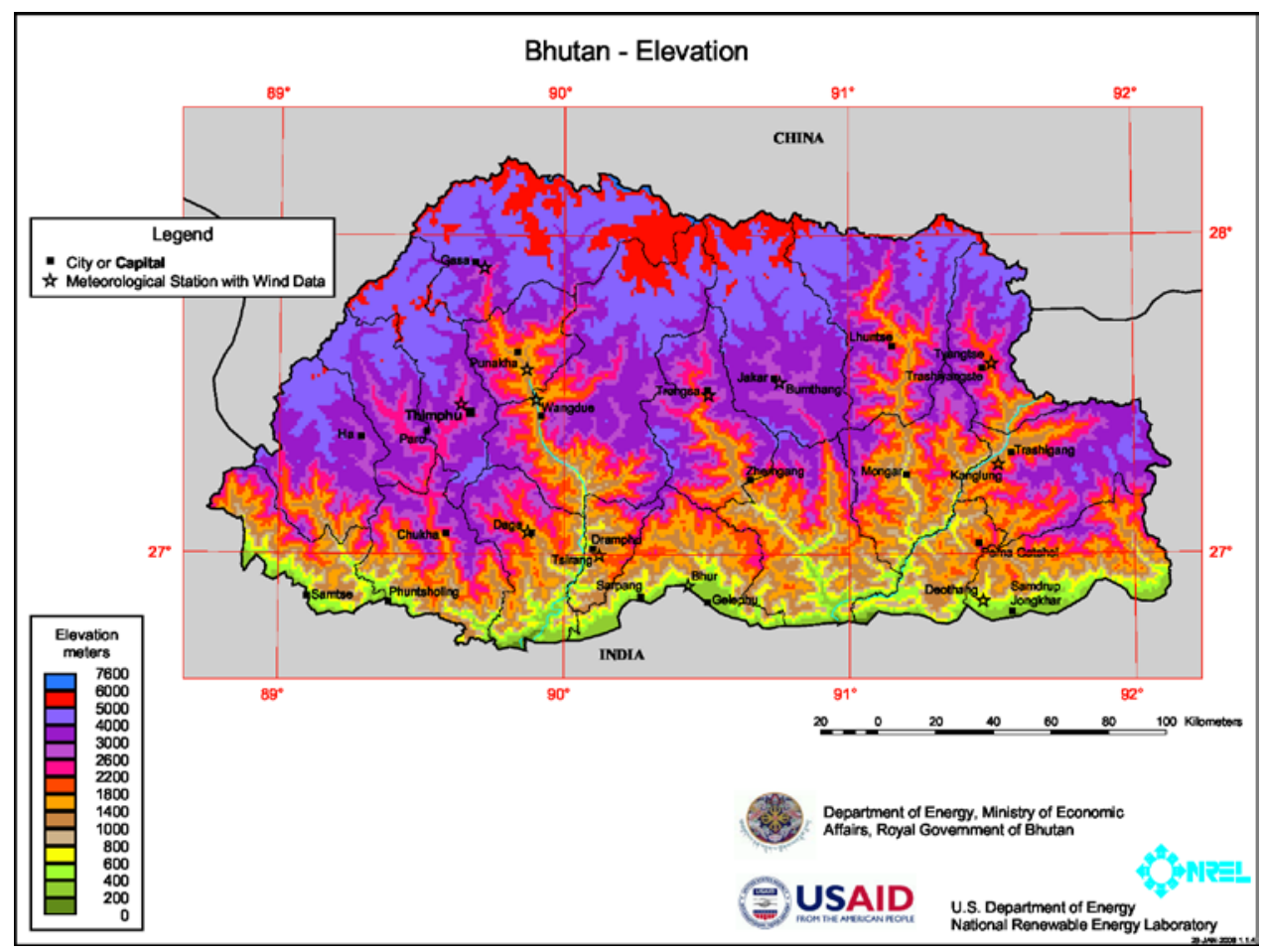

Figure 7. Elevation data used in the final phase of the wind resource analysis showing terrain complexity 


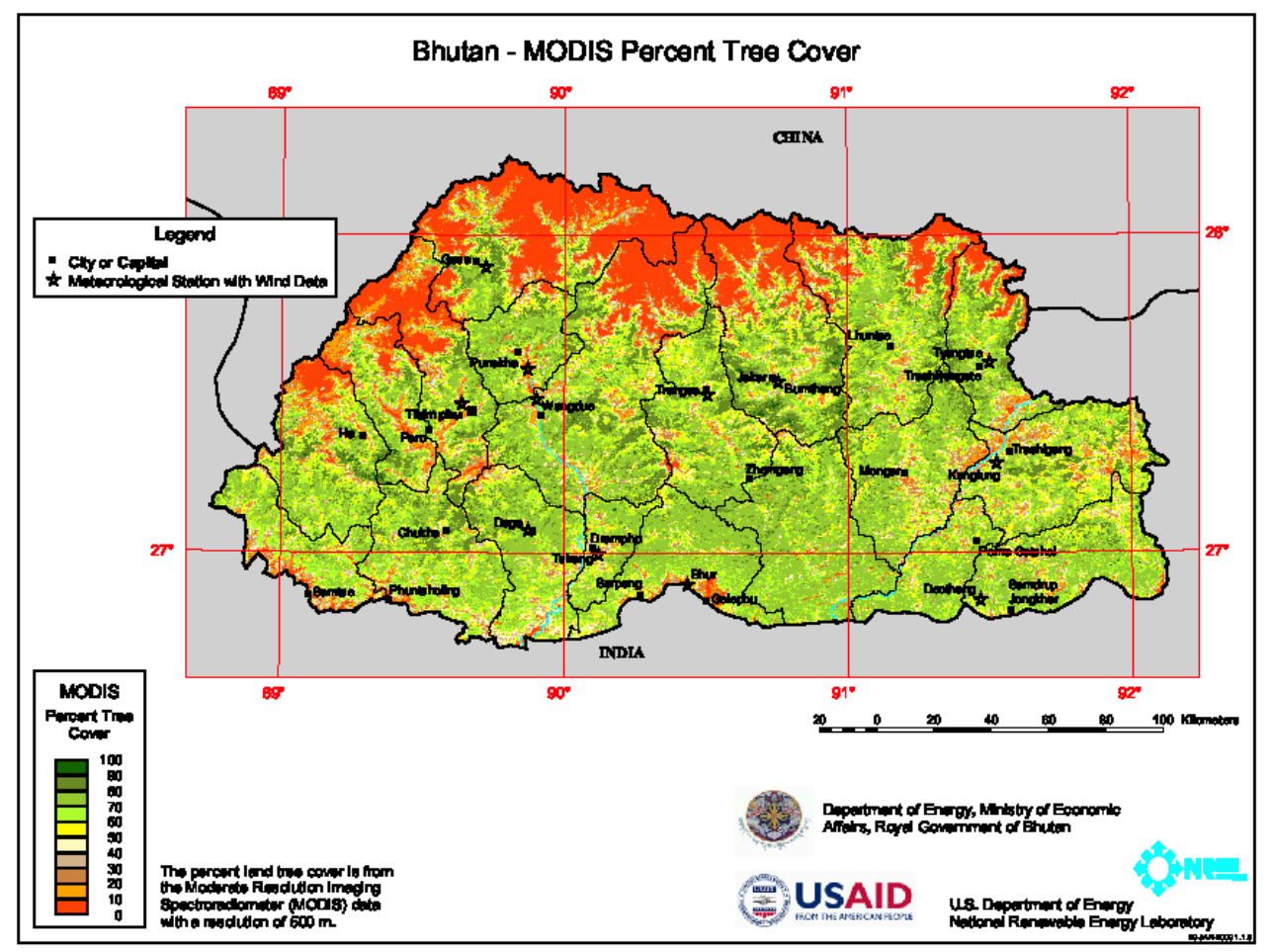

Figure 8. Tree cover data used in the final phase of the wind resource analysis showing land cover variation

In an evaluation of wind resource assessments for the United States, the model error in mean wind speed at $50 \mathrm{~m}$ was estimated to be $5-7 \%$, and the model error in wind turbine output was estimated to be $10-15 \%$ (Schwartz 2004). Model performance is likely to be poorer-and wind resource estimates are likely to have greater errors - in Bhutan than in other locations with less complex terrain and more dense measured wind data. An extensive wind monitoring program in Bhutan would allow for further validation and increased understanding of the local wind regimes.

\section{Wind Resource Maps}

Figure 9 shows the annual average wind power density map for Bhutan. NREL has posted fullsize versions of the maps, other data, documentation of the mapping methodology, and a general description of the wind resource on the NREL Web site (NREL 2009b). The NREL wind resource map collection includes maps of wind power density at 50 meters, with and without meteorological stations. The map of annual average wind power density can be used for preliminary investigation of potential sites for further study. Unlike the solar maps, the wind maps do not provide enough information to make project planning decisions. 


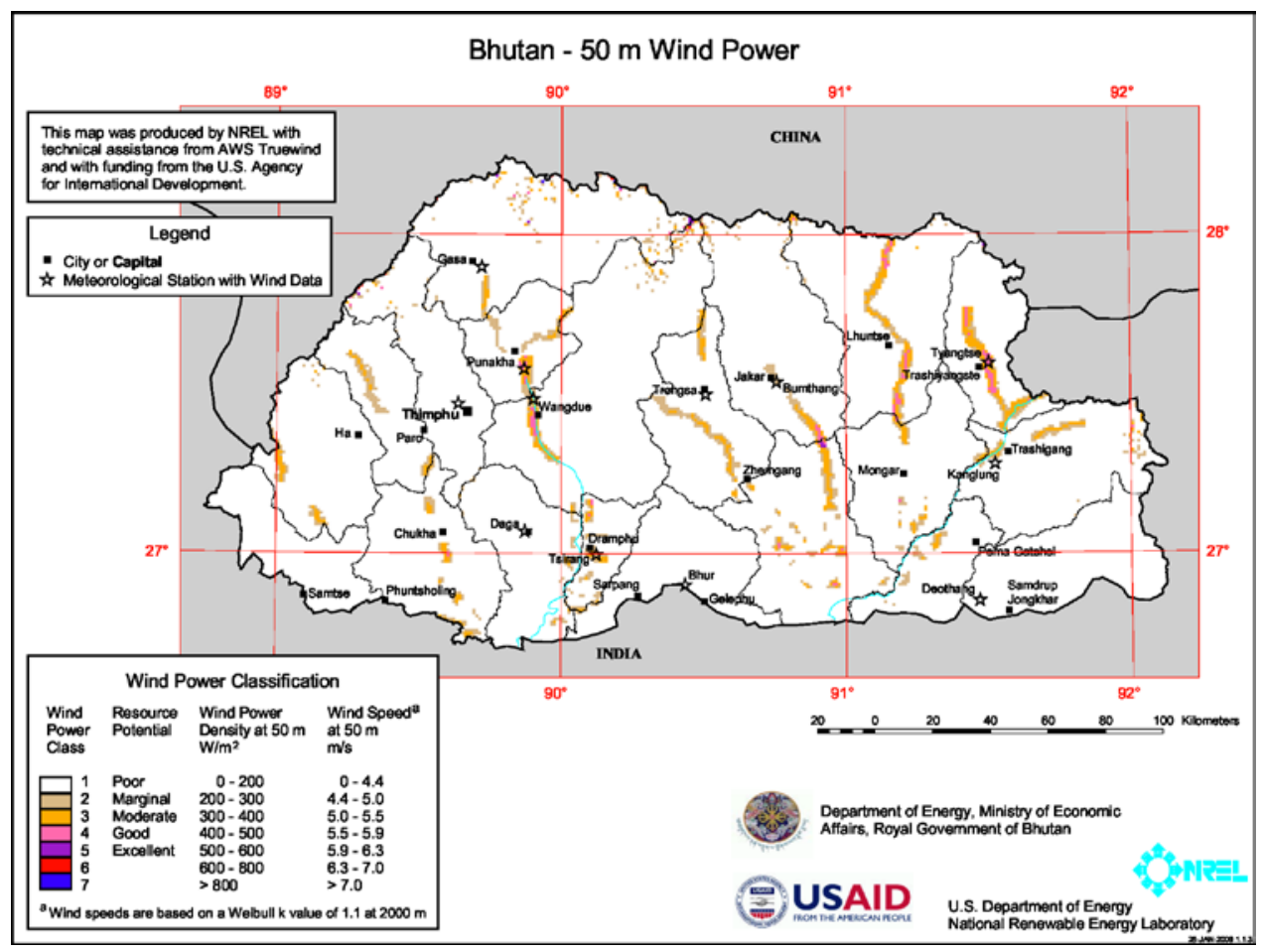

Figure 9. Annual wind power density at $\mathbf{5 0}$ meters

The wind power density map in Figure 9 shows areas with estimated wind resource of Class 3 and above in several valley areas throughout the country. In evaluations of sites for large-scale wind power generation projects, these Class 3 areas can be considered potential sites for groundbased resource measurement stations. Locations within areas with less than Class 3 wind resource may be suitable for small wind power projects, but these locations also require further study based on site visits and ground measurements.

The valleys near Wangdue and Punakha, Trashiyangtse, and Dungkhar indicate especially good wind resource. The map does not show the seasonal complexity of the wind resource in these valley areas. For example, data used in creating the map indicate strong springtime winds in the Punakha and Wangdue Valleys with strong daytime winds blowing from south to north throughout most of the year. The Tsirang Valley data indicated strong daytime winds blowing from north to south from late winter to early summer, and then blowing from the south from mid-summer through autumn. The data sets for Tsirang and Punakha Valleys both show stronger spring winds than autumn winds, although the variation is greater in Tsirang than in Punakha. The Trashiyangtse Valley has between Class 4 and Class 5 winds, considered good to excellent, with less seasonal variation than the other valleys. In the Trashiyangtse Valley, the windiest months are December to July, and strong daytime winds occur from August through November.

\section{Estimates of Wind Energy Development Potential}

The following estimates show the technical potential for wind power development under three scenarios representing different assumptions about land availability and wind turbine technology. Each of the scenarios is based on the wind power resource data used to develop the wind power density maps. Under each scenario, technical potential is typically orders of magnitude greater than the actual realizable installed capacity. For example, the American Wind Energy 
Association estimates a total installed capacity potential for the United States of 1,230,000 MW while the total installed capacity is about 28,000 MW (AWEA 2009b).

Each of the three scenarios includes estimates with and without protected areas. By virtue of their environmental attributes, wind power projects may be allowed in areas in Bhutan that are designated for environmental protection. However, wind energy projects in other countries are often challenged based on their environmental impact, such as habitat disruption, avian mortality, and impacts on nearby communities.

The scenarios make the following assumptions about the availability of land in windy areas for wind power development:

- Scenario 1 assumes that all land in windy areas is available for development. This assumption is consistent with NREL analyses for other countries, including Afghanistan and Pakistan (Elliot 2007).

- Scenario 2 assumes steep windy lands are not available for development. Steep areas are defined as terrain of $20 \%$ slope or greater.

- Scenario 3 assumes that only less steeply sloping (as defined in Scenario 2) windy areas within $5 \mathrm{~km}$ of roads and transmission lines are available for development.

The scenarios also require an estimate of the total installed capacity per square kilometer of land area. The estimate is based on assumptions about turbine density as determined by the size and number of turbines that can be installed in a given area.

Two wind turbine sizes were considered: $1.5-\mathrm{MW}$ and $750-\mathrm{kW}$ turbines. Because of their widespread use in U.S. projects, 1.5-MW turbines have been used for U.S. onshore production estimates. For Bhutan, the nature of the terrain and roads, which might limit truck length and weights, may make smaller turbines a better alternative. So, $750-\mathrm{kW}$ turbines were chosen for the smaller turbine scenarios.

- Scenario 1 uses a turbine capacity density of $5 \mathrm{MW} / \mathrm{km}^{2}$ based on $1.5-\mathrm{MW}$ turbines with $77-\mathrm{m}$ rotors installed at a turbine spacing of 5-rotor diameters in rows and 10-rotor diameters between rows. This scenario, which NREL has used for projections in other countries, allows reasonable spacing for a variety of terrains.

- Scenarios 2 and 3 use a turbine capacity density of $6.5 \mathrm{MW} / \mathrm{km}^{2}$ based on smaller 750$\mathrm{kW}$ turbines with the same spacing as the larger turbines in Scenario 1.

All three scenarios assume the wind turbine hubs are $50 \mathrm{~m}$ above ground.

\section{Scenario 1: Total Technical Wind Potential Estimate}

The total technical wind potential estimate assumes that all windy areas in Bhutan are available for development using the best available wind turbine technology given the possible transportation limitations described above.

- Only land with Class 3 or greater wind resource is included.

- Each square kilometer of land accommodates $5 \mathrm{MW}$ of installed capacity with individual 1.5-MW turbines. 
- The capacity factors applied to estimate annual energy predictions in million $\mathrm{kWhper}$ year are $32 \%, 36 \%, 40 \%, 44 \%$, and $47 \%$ for wind power Classes $3,4,5,6$, and 7 , respectively.

Table 10 shows the total potential capacity and electricity generation if all the theoretically available land in Bhutan were developed into wind plants using 1.5-MW wind turbines. These estimates should be considered as the maximum potential.

Table 10. Total technical wind potential estimate under Scenario 1

\begin{tabular}{|c|c|c|c|c|c|c|}
\hline & \multicolumn{3}{|c|}{ Excluding Protected Areas } & \multicolumn{3}{|c|}{ Including Protected Areas } \\
\hline $\begin{array}{l}\text { Wind } \\
\text { Power } \\
\text { Class } \\
\end{array}$ & $\begin{array}{l}\text { Land } \\
\text { Area } \\
\left(\mathrm{km}^{2}\right)\end{array}$ & $\begin{array}{c}\text { Installed } \\
\text { Capacity } \\
\text { (MW) }\end{array}$ & $\begin{array}{c}\text { Generation } \\
\text { (million } \\
\text { kWh/year) }\end{array}$ & $\begin{array}{l}\text { Land } \\
\text { Area } \\
\left(\mathrm{km}^{2}\right)\end{array}$ & $\begin{array}{l}\text { Installed } \\
\text { Capacity } \\
\text { (MW) }\end{array}$ & $\begin{array}{c}\text { Generation } \\
\text { (million } \\
\text { kWh/year) }\end{array}$ \\
\hline 3 & 596 & 2,981 & 8,356 & 783 & 3,916 & 10,977 \\
\hline 4 & 116 & 581 & 1,832 & 143 & 715 & 2,256 \\
\hline 5 & 11 & 54 & 188 & 21 & 104 & 365 \\
\hline 6 & 6 & 28 & 108 & 10 & 50 & 191 \\
\hline 7 & 5 & 26 & 109 & 8 & 40 & 165 \\
\hline Total & 734 & 3,670 & 10,592 & 965 & 4,825 & 13,954 \\
\hline
\end{tabular}

\section{Scenario 2: Smaller Wind Turbines and Slope Restriction}

The terrain of a potential wind site may impact its viability. For example, projects in areas with steep terrain may face higher construction costs associated with turbine installations. For Scenarios 2 and 3, a maximum terrain slope of $20 \%$ was used.

- Only land with Class 3 or greater wind resource is included.

- Only land with terrain slope less than $20 \%$ is included.

- Each square kilometer of developable land accommodates 6.5 MW of installed capacity with individual $750-\mathrm{kW}$ turbines.

- The capacity factors applied to estimate annual energy predictions in million $\mathrm{kWh}$ per year are $17 \%, 20 \%, 22 \%, 24 \%$, and $25 \%$ for wind Classes $3,4,5,6$, and 7 , respectively.

Table 11 shows the total technical potential for developing wind power in Bhutan using 750- kW wind turbines on land excluding areas with steep terrain. These turbines may be more practical for the mountainous roads of the country than the larger turbines analyzed in Scenario 1. 
Table 11. Total technical wind potential under Scenario 2

\begin{tabular}{|c|c|c|c|c|c|c|}
\hline \multirow[b]{2}{*}{$\begin{array}{l}\text { Wind } \\
\text { Power } \\
\text { Class }\end{array}$} & \multicolumn{3}{|c|}{ Including Protected Areas } & \multicolumn{3}{|c|}{ Excluding Protected Areas } \\
\hline & $\begin{array}{l}\text { Land } \\
\text { Area } \\
\left(\mathrm{km}^{2}\right)\end{array}$ & $\begin{array}{c}\text { Installed } \\
\text { Capacity } \\
\text { (MW) }\end{array}$ & $\begin{array}{c}\text { Generation } \\
\text { (million } \\
\text { kWh/year) }\end{array}$ & $\begin{array}{l}\text { Land } \\
\text { Area } \\
\left(\mathbf{k m}^{2}\right)\end{array}$ & $\begin{array}{c}\text { Installed } \\
\text { Capacity } \\
\text { (MW) }\end{array}$ & $\begin{array}{l}\text { Generation } \\
\text { (million } \\
\text { kWh/year) }\end{array}$ \\
\hline 3 & 59 & 384 & 572 & 47 & 306 & 456 \\
\hline 4 & 19 & 126 & 221 & 17 & 112 & 196 \\
\hline 5 & 3 & 20 & 39 & 2 & 13 & 25 \\
\hline 6 & 1 & 5 & 10 & 1 & 4 & 8 \\
\hline 7 & 1 & 7 & 16 & 1 & 6 & 14 \\
\hline Total & 83 & 542 & 857 & 68 & 441 & 698 \\
\hline
\end{tabular}

\section{Scenario 3: Smaller Turbines and Proximity to Roads Transmission Lines}

Most of Bhutan's road and electricity transmission infrastructure is located in valleys. NREL's wind maps show that some of the best wind resource is also located in valleys. This scenario describes the wind development potential in valleys that have both road and transmission infrastructure and good wind resource.

Scenarios 3 is based on the following assumptions:

- Only land with Class 3 or greater wind resource is included.

- Only land with terrain slope less than $20 \%$ is included.

- All land more than $5 \mathrm{~km}$ from transmission lines and roads is excluded.

- Each square kilometer of developable land accommodates 6.5 MW of installed capacity with individual $750-\mathrm{kW}$ turbines.

- The capacity factors applied to estimate annual energy predictions in gigawatt hours (GWh) per year are 17\%,20\%,22\%,24\%, and 25\% for wind Classes 3-7, respectively.

Table 12 shows the land available for wind power development is limited further than that shown in Scenario 2 by excluding all land further than $5 \mathrm{~km}$ from existing roads and transmission lines. The $75 \mathrm{MW}$ of installed capacity is estimated to generate about 120 million $\mathrm{kWh} / \mathrm{year}$ of electricity.

Table 12. Total technical wind potential under Scenario 3

\begin{tabular}{ccccccc}
\hline & \multicolumn{2}{c}{ Including Protected Areas } & \multicolumn{3}{c}{ Excluding Protected Areas } \\
\hline $\begin{array}{c}\text { Wind } \\
\text { Power } \\
\text { Class }\end{array}$ & $\begin{array}{c}\text { Land } \\
\text { Area } \\
\left.\mathbf{k m}^{\mathbf{2}}\right)\end{array}$ & $\begin{array}{c}\text { Installed } \\
\text { Capacity } \\
\mathbf{( M W )}\end{array}$ & $\begin{array}{c}\text { Generation } \\
\text { (million } \\
\mathbf{k W h} / \text { year) }\end{array}$ & $\begin{array}{c}\text { Land } \\
\text { Area } \\
\left.\mathbf{( k m}^{2}\right)\end{array}$ & $\begin{array}{c}\text { Installed } \\
\text { Capacity } \\
\mathbf{( M W )}\end{array}$ & $\begin{array}{c}\text { Generation } \\
\text { (million } \\
\mathbf{k W h} / \mathbf{y e a r})\end{array}$ \\
\hline 3 & 7 & 48 & 72 & 7 & 46 & 68 \\
4 & 5 & 30 & 53 & 5 & 29 & 51 \\
\hline Total & $\mathbf{1 2}$ & $\mathbf{7 8}$ & $\mathbf{1 2 4}$ & $\mathbf{1 2}$ & $\mathbf{7 5}$ & $\mathbf{1 2 0}$ \\
\hline
\end{tabular}




\section{Location of Areas with Good Wind Resource}

The following maps highlight those areas with Class 3 and above wind resource that are located near transmission lines.

Figure 10 shows that the valleys with most potential are the Wangdue, Lhuntse/Mongar, and Chukha Valleys. Figure 10 also shows a few other isolated areas that also show good wind potential, including locations in Zhemgang district and between Mongar and the Indian border.

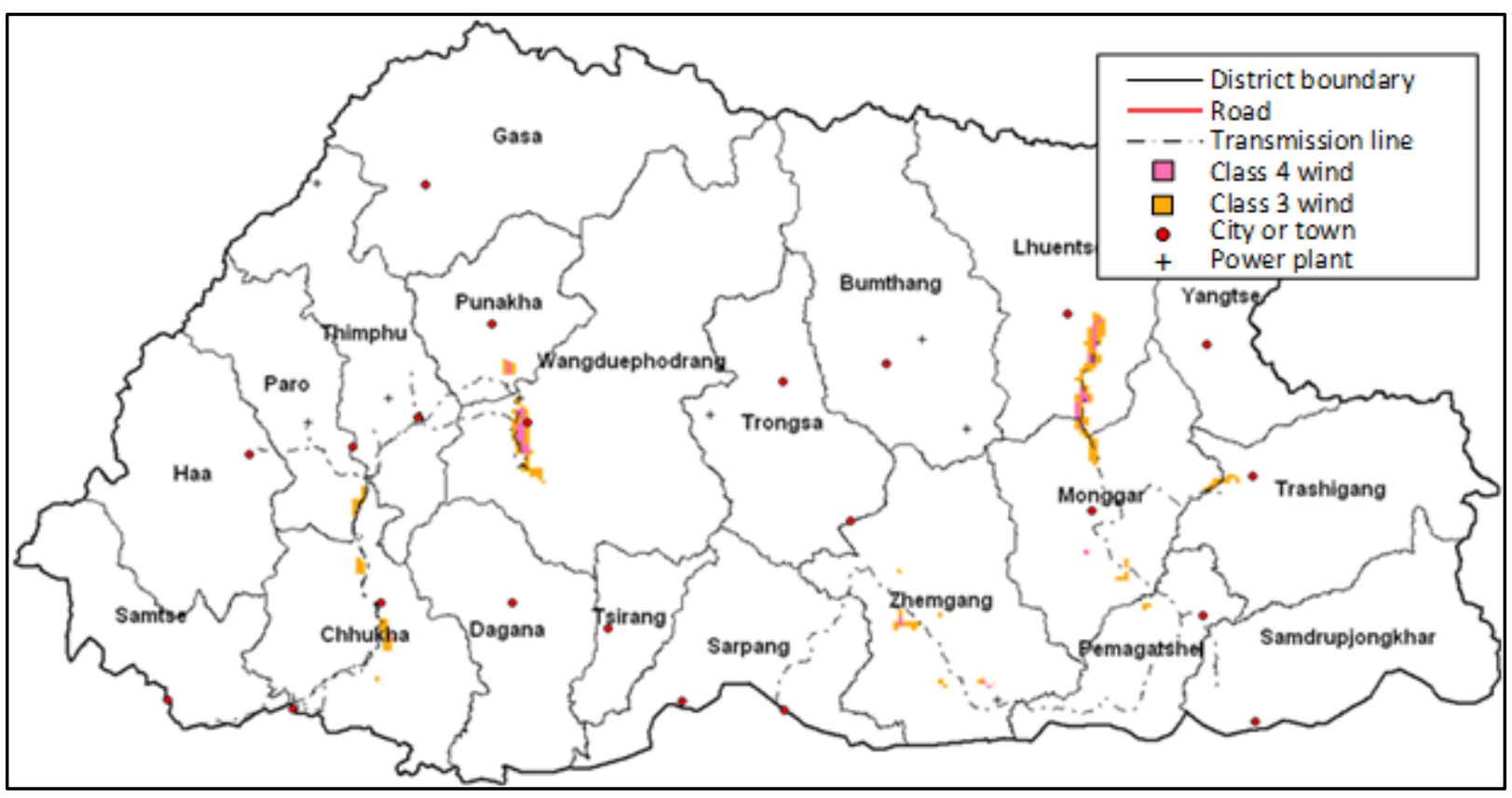

Figure 10. Wind power Class 3 and above within $5 \mathrm{~km}$ of transmission lines

Wangdue Valley is a good candidate for more wind studies. It has a good wind resource, is near both major roads and transmission lines, has relatively easy access to the capital city, and to the Phuntsholing-Thimphu national highway. Figure 11 shows the detail of the Wangdue Valley and areas near Thimphu with good wind resource and the road network that provides access to the valley. 


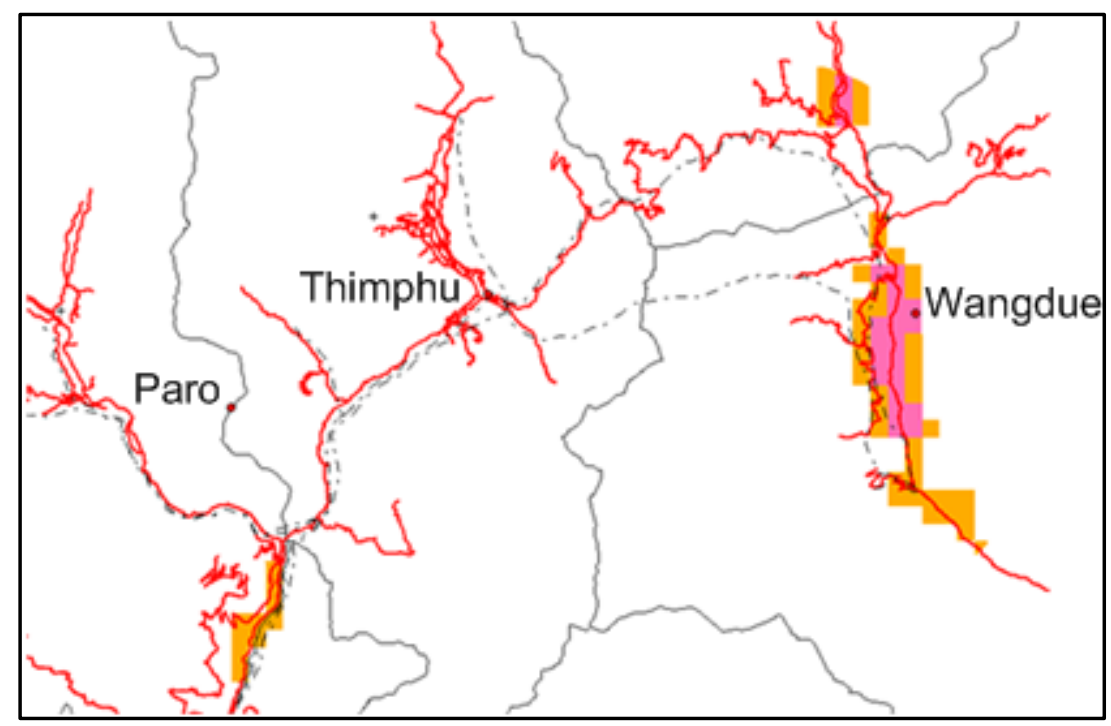

Figure 11. Wind resource in the vicinity of Thimphu

Figure 12 shows the area of good potential in the Chukha Valley. Although the area of good wind resource (represented by the number of rectangles) shown in Figure 12 is smaller than that in the Wangdue Valley shown in Figure 11 above, Chukha's proximity to Phuntsholing may make it a location for further exploration. The road between Phuntsholing and Wangdue offers the possibility of reduced logistical costs through coordinated wind measurement and project development activities in these areas.

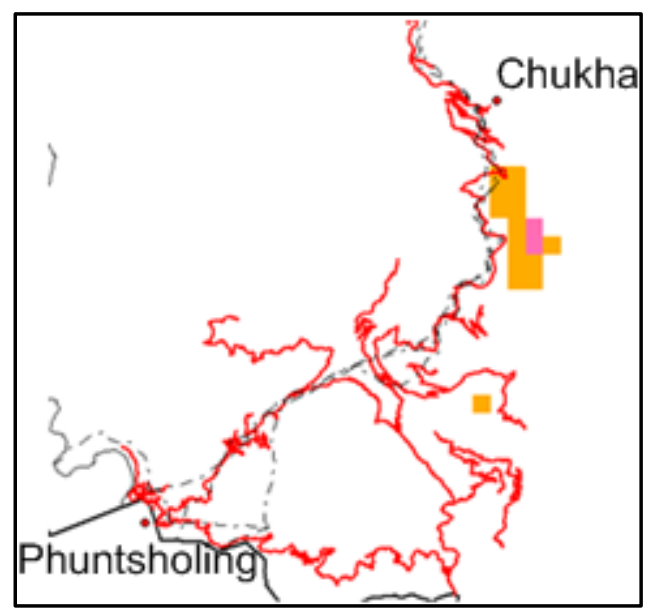

Figure 12. Wind resource in Chukha district 
Figure 13 shows the other large area with good wind resource in the Lhuntse Valley between Lhuntse and Mongar. As in the Wangdue Valley, Class 4 winds here occur near a major road and transmission line. The valley is a longer drive from Phuntsholing, so wind measurement and development projects in this area could involve higher costs. This area could be considered in a second phase, once the success of a pilot project has been demonstrated. Figure 13 also shows detail of the area of potential near Trashigang, which could possibly be explored at the same time as the Lhuntse Valley.

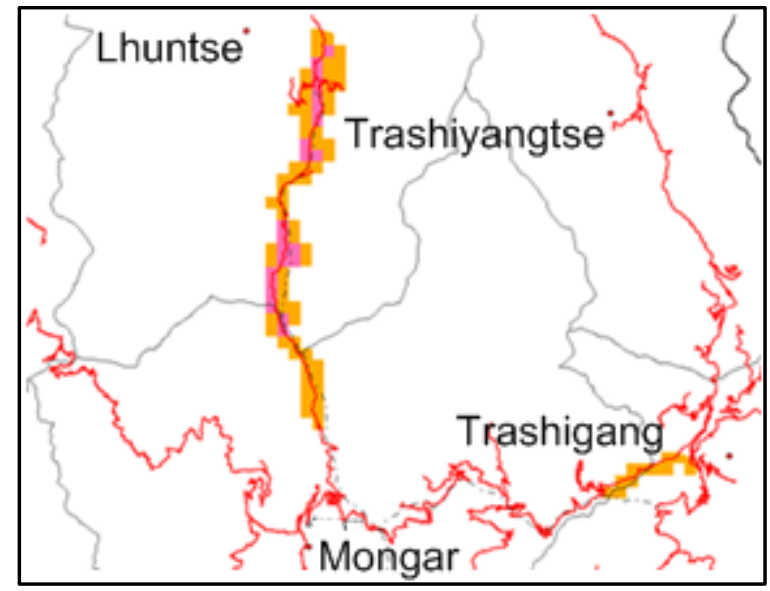

Figure 13. Wind resource in the Lhuntse Valley

Figure 14 shows the small areas of good potential in areas south of Mongar and Zhemgang that are near roads and transmission lines. These areas may be suitable for exploration after the Wangdue, Lhuntse, and Chukha resource has been developed.

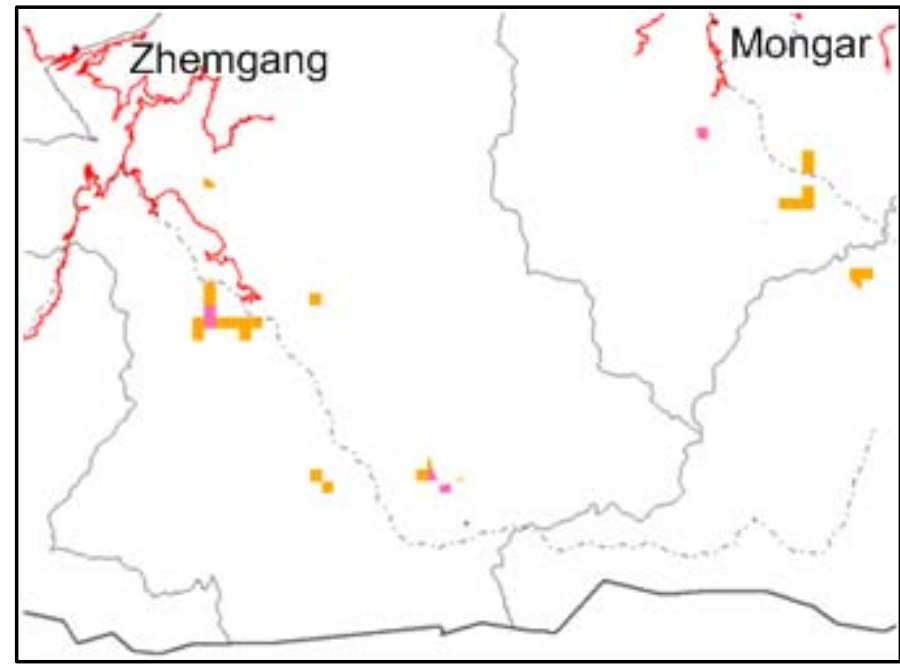

Figure 14. Small areas of good wind potential near the Indian border

\section{Cost of Developing Wind Power}

This information is provided to help analysts make rough estimates of the cost of developing wind power projects in Bhutan. Actual wind power projects costs vary widely depending factors such as the wind resource at the project site, cost of transportation to the site, the scale of the project, and labor costs. Current market prices are volatile and depend on various factors, 
including the supply and demand of wind turbine components, and the price of raw materials such as steel.

The American Wind Energy Association's fact sheet on the economics of wind energy uses costs from 1981 and 2000 to show how wind power projects costs have changed as wind turbine sizes have increased and technology has improved. In 1981, a $25-\mathrm{kW}$ turbine cost $\$ 2,600 / \mathrm{kW}$ and produced 45,000 kWh/year. In 2000, a 1,650-kW turbine cost $\$ 790 / \mathrm{kW}$ and generated 5.6 million $\mathrm{kWh} /$ year (AWEA 2005). Data from 2006 show installed costs for wind power projects in the United States ranging between $\$ 1,150 / \mathrm{kW}$ and $\$ 2,240 / \mathrm{kW}$, with an average of $\$ 1,480 / \mathrm{kW}$ (Wiser 2007).

The cost of wind systems for residential-scale grid-connected projects in the United States is in the range of $\$ 3,000 / \mathrm{kW}$ to $\$ 5,000 / \mathrm{kW}$. For example, a system based on a $3-\mathrm{kW}$ turbine might cost about $\$ 15,000$ to install while a $10 \mathrm{~kW}$ turbine might cost $\$ 35,000$ to $\$ 45,000$ (AWEA 2009a).

\section{Resource Map Applications}

The estimates of wind and solar resource development potential described in this report—and the accompanying maps - can support Bhutan's efforts to develop a national renewable energy policy, identify potential sites for exploration of a pilot wind farm, and identify potential locations for large-scale solar projects.

\section{National Renewable Energy Policy}

With its plentiful hydropower resource, Bhutan presents a unique case for the promotion of wind and solar resource development. The main benefit of solar and wind power-the displacement of carbon-based and imported fuels - is less relevant in Bhutan than elsewhere. Solar home systems can meet domestic lighting needs and does already play a role in Bhutan's rural electrification plan, but Bhutan does not need solar or wind power to meet unmet demand, so they do not play a major role in the country's current plans for large-scale power generation.

Although the country's hydropower resource is plentiful, it is potentially limited. Bhutan's water policy recognizes limitations in the hydro resource, including periodic water shortages resulting from non-hydropower uses such as human consumption and agriculture. These uses compete for water resources in localized areas and create seasonal resource fluctuations that contribute to hydropower plant inefficiencies. Floods and landslides contribute to rising sediment levels in rivers that feed the power plants (MoA 2003). The Druk Green Power Corporation has observed reduced output from some of its plants because of lower-than-expected inflow (Druk 2009). Uncertainties in weather projections that are associated with global climate change may also affect future hydropower production.

Furthermore, Bhutan's low cost of electricity will likely encourage increased domestic consumption of electricity, which may occur with: (1) an increase in residential and commercial use of electrical appliances, and (2) a potential increase in electricity use by newly attracted energy-intensive industries. As domestic consumption increases, competition for electricity earmarked for domestic use may increase, driving up prices and making alternative sources look more attractive. 
A comprehensive national renewable energy policy would support Bhutan's continued hydropower resource development and promote the development of other renewable energy resources, including wind and solar. Solar and wind power projects may benefit Bhutan by:

- Diversifying resources for domestic electricity consumption, thereby hedging against limitations of the hydropower supply and increased domestic demand

- Developing domestic research and development capabilities

- Creating jobs in the engineering, financial, and skilled trades sectors

- Potentially reducing the dependence on imported fossil and wood fuels for domestic and commercial heating needs.

A national renewable energy policy in Bhutan would identify the benefits of renewable energy projects and provide a framework for developing projects. One element of such a policy would be the quantification of the potential of solar and wind resource. The NREL wind and solar maps and analysis presented in this paper can contribute to a renewable energy policy by:

- Providing a basis for a discussion of the solar and wind potential

- Showing areas with promise for further study of the wind resource

- Identifying sites for solar project development.

\section{Wind Measurement Program}

The wind resource data presented in the NREL maps and data are based on upper atmosphere measurements, computer modeling, and measurements at 12 ground stations. The data show areas of potential resource but are not of sufficient quality to use for making decisions that involve large investments. The data do show areas of promise for further wind resource studies.

A wind measurement program will serve Bhutan by:

- Providing detailed information about the wind resource in areas with promising resource suggested by the NREL wind map

- Enhancing the information provided by previous wind measurement programs, specifically providing information about the wind resource at wind turbine hub heights as well as information about wind shear

- Providing quality wind resource data for use in planning the pilot wind power generation project included in the Asian Development Bank's lending program for 2009-2011

- Contributing to a better understanding of the wind resource in Bhutan's complex terrain, thereby helping to attract potential investors.

A wind measurement program involves four stages:

- Screening for areas with good potential

- Conducting site visits to study conditions at locations identified in screening

- Monitoring wind speed at promising locations for at least one year

- Identifying locations with good measured resource for individual turbines. 
Sites on the NREL wind power class map that are good candidates for site visits and wind monitoring study have the following characteristics:

- Wind power Class 3 or above, which ensures a sufficient resource

- Proximity to roads and transmission lines, which reduces transportation and interconnection costs

- Proximity to load centers, which minimizes transmission losses.

The map suggests that the Wangdue and Lhuntse Valleys have sites that meet the above characteristics. The Wangdue Valley has additional characteristics that may make it more favorable for initial further study:

- Proximity to Thimphu would minimize travel costs for site visits, assuming that project staffs are located in Thimphu. This would also facilitate site visits by potential investors and other interested parties.

- Relative proximity to Phuntsholing would minimize transportation costs for equipment arriving from India.

- Near-Thimphu transmission network would help supply capital city's electricity demand.

Wind measurement systems should measure wind speed and direction at turbine hub height and include sensors at different heights to measure wind shear. Because of Bhutan's complex terrain, additional measurements will improve the quality of the data available for understanding the wind resource. Data collected at different locations in the valleys can be used understand the terrain's effect on wind. 


\section{References}

American Wind Energy Association, AWEA. (2005) "The Economics of Wind Energy." Wind Energy Fact Sheets. http://www.awea.org/pubs/factsheets/EconomicsOfWind-Feb2005.pdf. Accessed August 13, 2009.

American Wind Energy Association, AWEA. (2009a). "The Economics of Small Wind." Small Wind Factsheets. http://www.awea.org/smallwind/toolbox/TOOLS/factsheet_economics.pdf. Accessed August 17, 2009.

American Wind Energy Association, AWEA. (2009b). "U.S. Wind Energy Projects." Resources. http://www.awea.org/projects/. Accessed June 1, 2009.

Central Intelligence Agency, CIA. (2009). "Bhutan." The World Factbook.

https://www.cia.gov/library/publications/the-world-factbook/geos/bt.html/. Accessed May 28, 2009.

Druk Green Power Corporation Limited. (2008) "Performance Highlights." Druk Green Power Corporation Limited. http://www.dgpc.bt/Performance.html. Accessed June 1, 2009.

Elliot, D. (2007). "Wind Resource Assessment and Mapping for Afghanistan and Pakistan." NREL Resource Maps and Toolkit for Pakistan.

http://www.nrel.gov/applying_technologies/pakistan/wind/pdfs/afg_pak_wind_june07.pdf. Accessed June 1, 2009.

Gyeltshen, M.; Tshering K. (2008). "Renewable Energy Programmes in Bhutan." South Asia Regional Initiative for Energy. http://www.sari-energy.org/PageFiles/What_We_Do/activities/ Renewable_Energy_April_2008/Bhutan_Renewable_Energy_Program.pdf. Accessed May 28, 2009.

Gyeltshen, M. (2006). Distributed Renewable Energy Systems for Rural Electrification. Master's Thesis. Delft: The Netherlands: Delft University of Technology..

Gyeltshen, M. (2009a). Conversation with Author April 3, 2009. Thimphu, Bhutan.

Gyeltshen, M. (2009b). Email with Author July 15, 2009.

Kirby, M.; Dahle, D.; Heimiller, D.; Farhar, B.; Owens, B. (2003). Assessing the Potential for Renewable Energy on Public Lands. DOE/GO-102003-0704. Washington, DC: U.S. Department of the Interior and U.S. Department of Energy.

Ministry of Agriculture of the Royal Government of Bhutan, MoA. (2003). "Bhutan Water Policy." Legislations.

http://www.moa.gov.bt/moa/downloads/downloadFiles/MoADownload8uv5955mb.pdf. Accessed August 17, 2009. 
Myers, D.; Wilcox, S.; Marion, W.; George, R.; Anderberg, M. (2005). "Broadband model performance for an updated national solar radiation database in the United States of America." In: Proceedings of ISES 2005 Solar World Congress, Orlando, FL.

National Renewable Energy Laboratory, NREL. (2009a) "NREL Solar Products for Bhutan." NREL Resource Maps and Toolkit for Bhutan.

http://www.nrel.gov/applying_technologies/ra_bhutan.html. Accessed June 2, 2009.

National Renewable Energy Laboratory, NREL. (2009b). "NREL Wind Products for Bhutan." NREL Resource Maps and Toolkit for Bhutan.

http://www.nrel.gov/applying_technologies/ra_bhutan.html. Accessed June 2, 2009.

National Renewable Energy Laboratory, NREL. (2009c). "DC to AC Derate Factor." Changing System Parameters. http://rredc.nrel.gov/solar/codes_algs/PVWATTS/system.html. Accessed August 8, 2009.

Perez, R.; Ineichen, P.; Moore, K.; Kmiecik, M.; Chain, C.; George, R.; Vignola, F. (2002).

"A New Operational Satellite-to-Irradiance Model." Solar Energy (73:5); pp 307-317.

Schwartz, M.; Elliott, D. (2004). Validation of Updated State Wind Resource Maps for the United States. NREL Report No. CP-500-36200

Solarbuzz. (2009a). "Solar Module Retail Price Environment." Solarbuzz. http://www.solarbuzz.com/Moduleprices.htm. Accessed August 17, 2009.

Solarbuzz. (2009b). "Solar Electricity Prices: August 2009." Solarbuzz. http://www.solarbuzz.com/SolarPrices.htm. Accessed August 17, 2009.

Uddin, S.; Ros, T.; Xiaojiang, Y. (2007). "Energy Environment and Development in Bhutan." Renewable and Sustainable Energy Reviews (11); pp 2083-2103.

Western Governors' Association, WGA. (2006). Solar Task Force Report. Western Governors' Association Clean and Diversified Energy Initiative.

Wiser, R.; Bolinger, M. (2007). Annual Report on U.S. Wind Power Installation, Cost, and Performance Trends: 2006. Washington, DC: U.S. Department of Energy. 


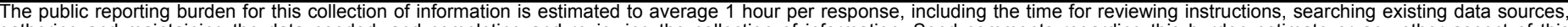



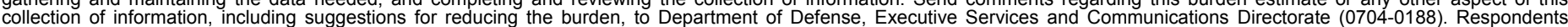

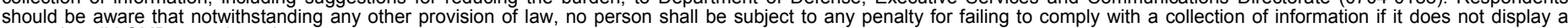

should be aware that notwithstanding

PLEASE DO NOT RETURN YOUR FORM TO THE ABOVE ORGANIZATION.

\begin{tabular}{l|l|l|l} 
1. REPORT DATE $(D D-M M-Y Y Y Y)$ & 2. & REPORT TYPE & 3. DATES COVERED (FrOm - TO)
\end{tabular} September 2009

Technical Report

4. TITLE AND SUBTITLE

Potential for Development of Solar and Wind Resource in Bhutan 5a. CONTRACT NUMBER

DE-AC36-08-GO28308

5b. GRANT NUMBER

5c. PROGRAM ELEMENT NUMBER

5d. PROJECT NUMBER

NREL/TP-6A2-46547

5e. TASK NUMBER

WF3N.8001

5f. WORK UNIT NUMBER
7. PERFORMING ORGANIZATION NAME(S) AND ADDRESS(ES)

National Renewable Energy Laboratory

1617 Cole Blvd.

Golden, CO 80401-3393
8. PERFORMING ORGANIZATION REPORT NUMBER

NREL/TP-6A2-46547

9. SPONSORING/MONITORING AGENCY NAME(S) AND ADDRESS(ES)

10. SPONSOR/MONITOR'S ACRONYM(S) NREL

11. SPONSORING/MONITORING AGENCY REPORT NUMBER

12. DISTRIBUTION AVAILABILITY STATEMENT

National Technical Information Service

U.S. Department of Commerce

5285 Port Royal Road

Springfield, VA 22161

13. SUPPLEMENTARY NOTES

14. ABSTRACT (Maximum 200 Words)

With support from the U.S. Agency for International Development (USAID), the U.S. Department of Energy's National Renewable Energy Laboratory (NREL) produced maps and data of the wind and solar resources in Bhutan. The solar resource data show that Bhutan has an adequate resource for flat-plate collectors, with annual average values of global horizontal solar radiation ranging from 4.0 to $5.5 \mathrm{kWh} / \mathrm{m} 2$-day (4.0 to 5.5 peak sun hours per day). The information provided in this report may be of use to energy planners in Bhutan involved in developing energy policy or planning wind and solar projects, and to energy analysts around the world interested in gaining an understanding of Bhutan's wind and solar energy potential.

15. SUBJECT TERMS

Bhutan; wind resource; solar resource; NREL; USAID; U.S. Agency for International Development; energy analysis; energy policy; energy planning; resource potential; international activities; global energy

\begin{tabular}{|c|c|c|c|c|}
\hline \multicolumn{3}{|c|}{ 16. SECURITY CLASSIFICATION OF: } & \multirow{2}{*}{$\begin{array}{l}\text { 17. LIMITATION } \\
\text { OF ABSTRACT } \\
\text { UL }\end{array}$} & \multirow{2}{*}{$\begin{array}{l}\text { 18. NUMBER } \\
\text { OF PAGES }\end{array}$} \\
\hline $\begin{array}{l}\text { a. REPORT } \\
\text { Unclassified }\end{array}$ & $\begin{array}{l}\text { b. ABSTRACT } \\
\text { Unclassified }\end{array}$ & $\begin{array}{l}\text { c. THIS PAGE } \\
\text { Unclassified }\end{array}$ & & \\
\hline
\end{tabular}

19a. NAME OF RESPONSIBLE PERSON

19b. TELEPHONE NUMBER (Include area code) 